\title{
1958-2006 Precipitation Climatology \\ for \\ Lawrence Livermore National Laboratory \\ Livermore Site and Site 300
}

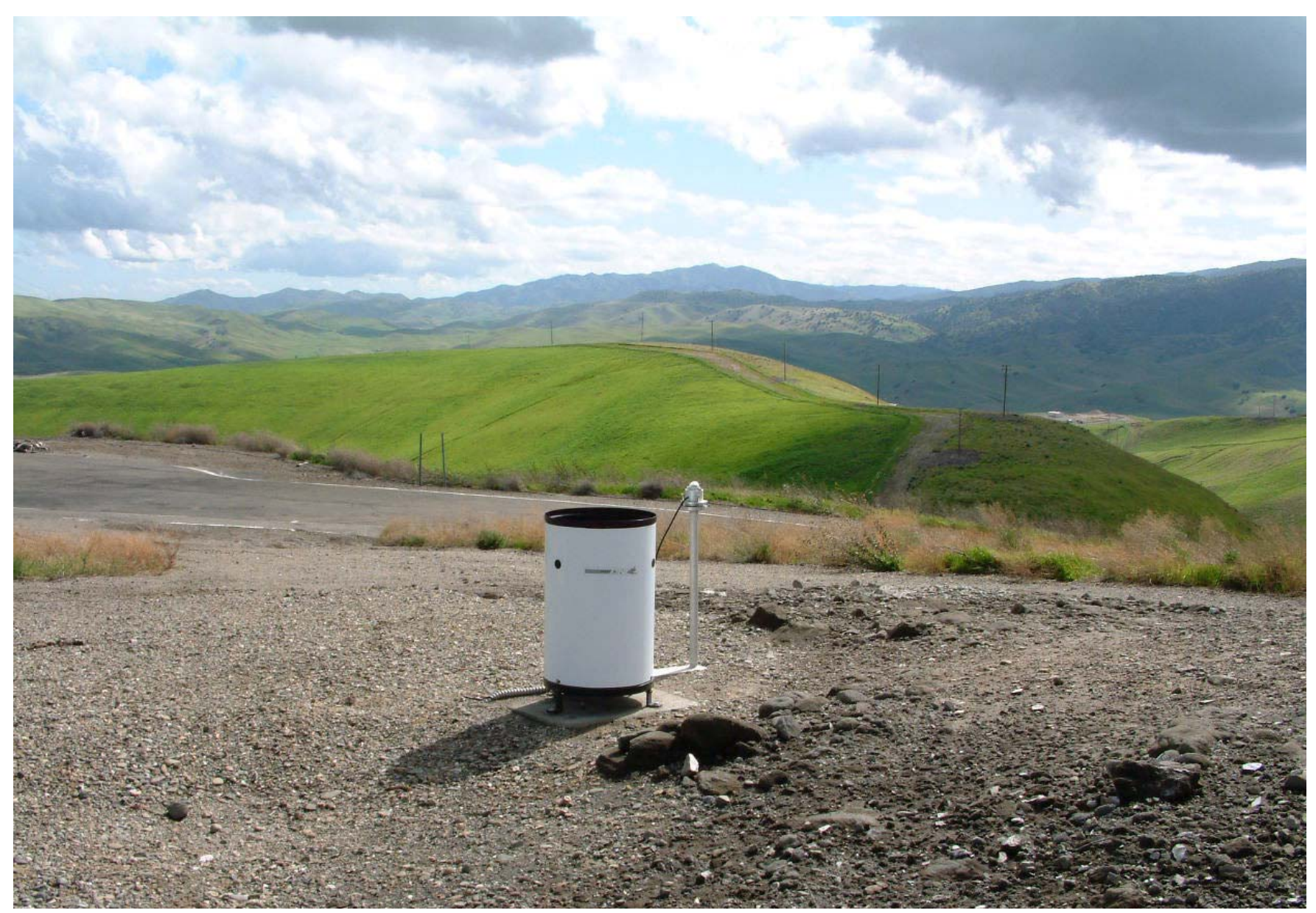

Photo by Gary Bear

\author{
Brent M. Bowen \\ Environmental Protection Department \\ Lawrence Livermore National Laboratory \\ March 2, 2007
}




\section{Disclaimer}

This document was prepared as an account of work sponsored by an agency of the United States Government. Neither the United States Government nor the University of California nor any of their employees, makes any warranty, express or implied, or assumes any legal liability or responsibility for the accuracy, completeness, or usefulness of any information, apparatus, product, or process disclosed, or represents that its use would not infringe privately owned rights. Reference herein to any specific commercial product, process, or service by trade name, trademark, manufacturer, or otherwise, does not necessarily constitute or imply its endorsement, recommendation, or favoring by the United States Government or the University of California. The views and opinions of authors expressed herein do not necessarily state or reflect those of the United States Government or the University of California, and shall not be used for advertising or product endorsement purposes.

This work was performed under the auspices of the U.S. Department of Energy by University of California, Lawrence Livermore National Laboratory under Contract W-7405-Eng-48. 


\section{Contents}

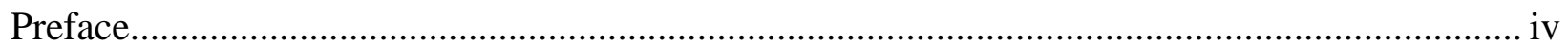

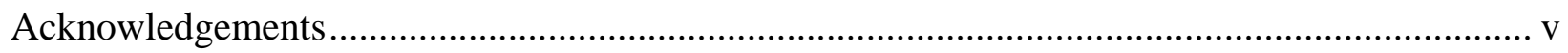

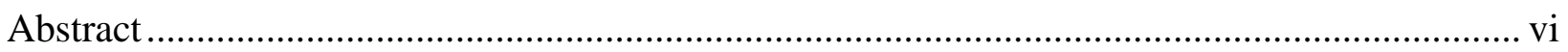

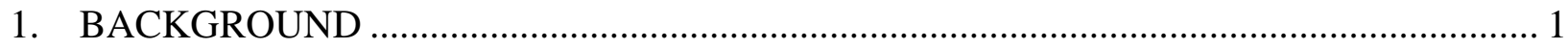

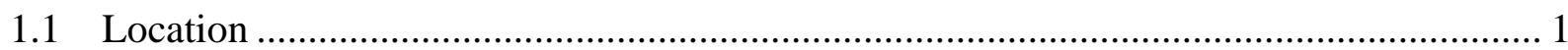

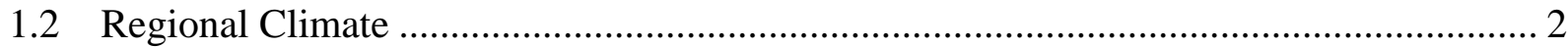

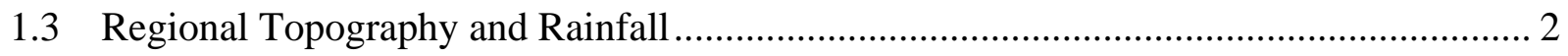

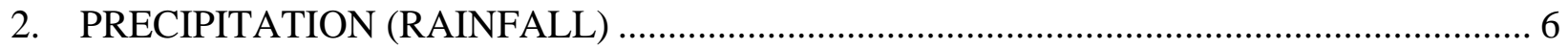

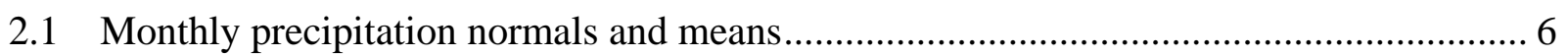

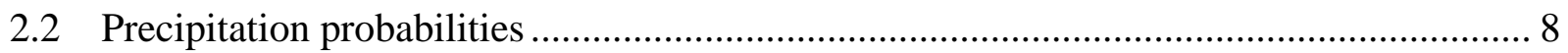

2.3 Number of days with precipitation exceeding specified amounts. ................................ 8

3. PRECIPITATION-FREQUENCY AND EXTREME VALUE ANALYSIS.......................... 12

4. HOURLY PRECIPITATION MEANS and FREQUENCIES. ........................................ 18

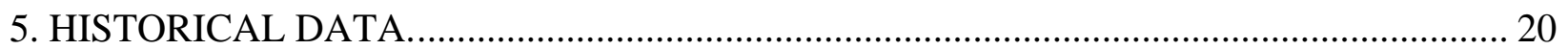

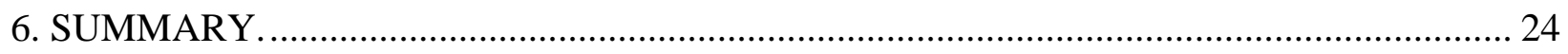

Appendix A. Location of Livermore Site Rain Gauge and Meteorological Tower..................... 25

Appendix B. Location of Site 300 Rain Gauge and Meteorological Tower............................... 26

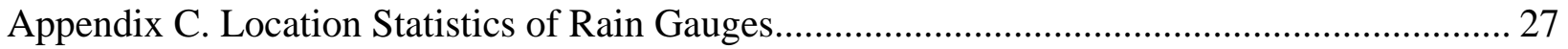

Appendix D. Rain Gauge History and Estimated Accuracy................................................... 28

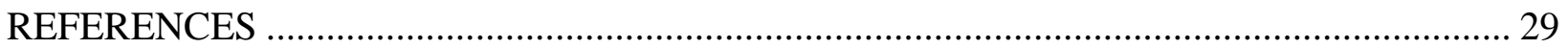




\section{Figures}

Figure 1.1 Locations of LLNL Livermore site and Site 300. 1

Figure 1.2. Aerial view looking toward the south showing the Livermore meteorological tower and rain gauge site and surrounding area. The tower and rain gauge are located in an open field within the triangle slightly below center of picture.

Figure 1.3. View toward the south-southeast of the Site 300 rain gauge looking (Photo by Gary Bear).... 4

Figure 1.4. Map showing regional terrain above 1000 feet above sea level and annual normal (19712000) precipitation. (Map created August 29, 2006 with data downloaded from ocs.orst.edu/prism/. Copyright @ 2005, PRISM Group, Oregon State University) ......................5

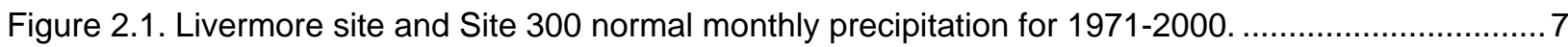

Figure 3.1. Seasonal extreme precipitation analysis for the Livermore site (1958-1959 through 2005-2006) and Site 300 (1959-1960 through 2005-2006).

Figure 3.2. Monthly extreme precipitation analysis for the Livermore site (1958-1959 through 2005-2006) and Site 300 (1959-1960 through 2005-2006).

Figure 3.3. Short duration extreme precipitation analysis for the Livermore site (1989-1990 through 2005-2006).

Figure 3.4. Short duration extreme precipitation analysis for Site 300 (1989-1990 through 2005-2006)...17

Figure 4.1. Mean hourly (Pacific Standard Time) precipitation amounts and frequencies at the Livermore site and Site 300 during winter (December to February), spring (March to May), summer (June to August), and fall (September to November). The bars represent precipitation amounts and the lines represent frequencies. The means are based on 15-minute measurements taken from August 1989 - August 2006 at the Livermore site and from January 1989 - August 2006 at Site 300.

Figure 5.1. Livermore site historical seasonal precipitation. Black dashed line indicates mean over entire measurement period.

Figure 5.2. Site 300 historical seasonal precipitation. Black dashed line indicates mean over entire measurement period.

Appendix A. Location of Livermore Site Rain Gauge and Meteorological Tower 25

Appendix B. Location of Site 300 Rain Gauge and Meteorological Tower 26 


\section{Tables}

Table 2.1. Livermore site and Site 300 monthly and annual precipitation normals and medians (1971 to 2000) in inches.

Table 2.2 Livermore site precipitation probabilities, 1958-2006. Column headings represent percentage of time precipitation is less than, or equal to, the specified amount for a given month, year, or season.

Table 2.3. Site 300 precipitation probabilities, 1959-2006. Column headings represent percentage of time precipitation is less than or equal to the specified amount for a given month, year, or season..9

Table 2.4. Livermore site mean and median number of days of precipitation for specified amounts, maximum number of days in which rainfall exceeded the specified amount, and latest year in which the maximum occurred. The period of record is 1989-2006. An asterisk denotes latest year for multiple occurrences.

Table 2.5. Site 300 mean and median number of days of precipitation for specified amounts, maximum number of days in which rainfall exceeded the specified amount, and latest year in which the maximum occurred. The period of record is 1989-2006. An asterisk denotes latest year for multiple occurrences.

Table 3.1 Estimated precipitation for various return periods and time periods at the Livermore site and Site 300 . The return periods and analyses are based on rainfall seasons (July 1 through June 30)

Table 5.1. Livermore site and Site 300 seasonal and annual precipitation. Seasonal precipitation is rainfall for the 12-month period ending on June 30 of the indicated year.....

Table 5.2. Livermore site and Site 300 seasonal and annual precipitation. The 30 -year means (normals) and medians for seasonal rainfall start and end on July 1 and June 30, respectively, on the indicated years.

Appendix C. Location Statistics of Rain Gauges .27

Appendix D. Rain Gauge History and Estimated Accuracy 28 


\section{Preface}

This report was written and is intended for a wide audience of readers, from scientists, engineers, and technologists who can use the data directly, to individuals who want to know rainfall patterns at Lawrence Livermore National Laboratory’s (LLNL) Livermore site and Site 300. For this reason, and because the English units of inches (in.) continue to be the standard in National Oceanic and Atmospheric Administration (NOAA) reporting and publications as well as many engineering documents, the familiar unit of inches is used primarily in this report. The metric unit of centimeters $(\mathrm{cm})$ is also displayed on second ordinates of most graphs. In keeping with meteorological convention, the mention of "wind direction" refers to the direction from which the wind blows.

This report complements a previously published LLNL climatology report (Gouveia and Chapman, 1989) that contains primarily wind and turbulence coefficients, temperature, and humidity analyses. A climatology report is planned for 2011 that will include analyses of updated 30-year temperature and rainfall normals, wind, temperature, and humidity measurements at the Livermore site and Site 300. This comprehensive report will include data from the 170-foot (52-m) towers recently installed at the Livermore site (2005) and Site 300 (2006) and include additional measurements such as vertical turbulence coefficients, evaporation, soil temperature, moisture and heat flux, solar and infrared radiation, and atmospheric pressure.

The Terrestrial and Atmospheric Monitoring and Modeling (TAMM) Group of the Environmental Protection Department (EPD) at LLNL is responsible for meteorological monitoring and analysis to support emergency and regulatory dispersion modeling, Laboratory field activities and operations, and special studies. Rainfall data are used to support hydrological monitoring and studies, environmental sampling scheduling, Laboratory operations (e.g., sewage flow, etc.) and in atmospheric dispersion models to estimate washout from toxic plumes.

Finally, because snowfall is so rare and hail is so infrequent, measurable precipitation is virtually equivalent to and interchangeable with "rainfall” at both sites. Therefore the terms precipitation and rainfall are used interchangeably throughout this report. 


\section{Acknowledgements}

The following people at LLNL are credited for their assistance. I thank Gary Bear for his hard work and dedication in maintaining and servicing the meteorological instruments at the towers. I also appreciate Frank Gouveia for his contribution in quality assurance and analysis of rainfall data. I value numerous discussions with Ring Peterson in which she made me realize that thorough quality assurance, review, analysis, and documentation of the entire rainfall record at the Livermore site and Site 300 were necessary to adequately support the Laboratory's mission. Ring Peterson, Chris Campbell and Gretchen Gallegos reviewed this document and made it more understandable and instructive with their helpful comments and suggestions.

Maurina Sherman skillfully edited and assisted with the layout of this report. I am grateful to Brett Clark for his assistance with the figures and Kathy O’Connor for her effort in formatting two very large tables. 


\begin{abstract}
This report contains rainfall climatology and analyses during the period from 1958 to 2006 for the two sites of Lawrence Livermore National Laboratory: the Livermore site and Site 300. The measurement sites are described, a regional climatology overview is provided, and the effect of topography on regional precipitation is discussed. Rainfall statistics are presented including monthly normals (30-year means) and medians; percentages of time that rainfall is less than or equal to specified amounts for given months, years, and seasons; and mean, median, and maximum numbers of days of precipitation for specified amounts by month, year, and season. The rainfall pattern is demonstrated to be typical of Mediterranean climates, with most rain falling during the cold season. Nearly $80 \%$ of seasonal rainfall occurs during November through March, with the average annual rainfall equaling 13.62 and 10.64 inches at the Livermore site and Site 300, respectively. Precipitation frequency and extreme value analyses for durations ranging from 15 minutes to 24 hours, month, and rainfall season are shown in order to estimate rainfall amounts for return periods of two to 100 years at both sites. This analysis determined 100-year return periods for largest 24-hour rainfalls of 2.49 and 2.22 inches at the Livermore site and Site 300, respectively. Historical analysis of seasonal rainfall data indicates that the wettest rainfall seasons at both sites typically occurred during strong El Niños.
\end{abstract}




\section{BACKGROUND}

\subsection{Location}

LLNL consists of two sites - the Livermore site located in Livermore, California in Alameda County and the Experimental Test Site (Site 300) located near Tracy, California, in San Joaquin and Alameda counties (Figure 1.1). The Livermore site occupies an area of 1.3 square miles $\left(3.3 \mathrm{~km}^{2}\right)$, including the land that serves as a buffer zone around the site. Immediately to the south is Sandia National Laboratories/California. There are also some low-density residential areas and agricultural areas devoted to grazing, orchards, and vineyards to the south of the Livermore site. A small business park lies to the southwest. Farther south, property is primarily open space and ranchettes with some agricultural use. Single-family dwellings and apartments lie immediately to the west. A very small amount of low-density residential development lies to the east of the Livermore site and agricultural land extends to the foothills at the eastern edge of the Livermore Valley. A business park is located to the north, and a 500-acre (200-hectare) parcel of open space to the northeast has been rezoned to allow development of light industry.

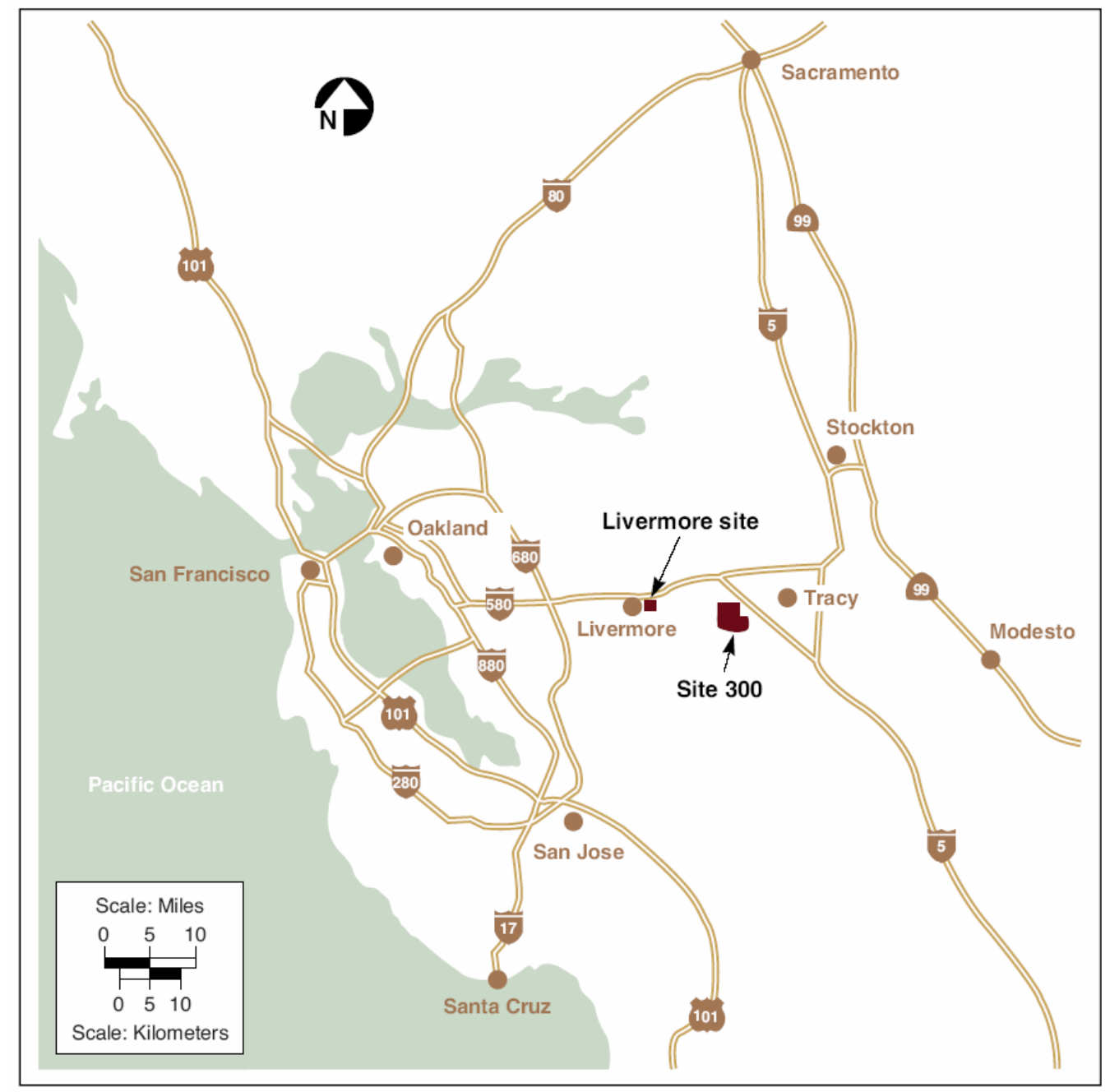

Figure 1.1

Locations of LLNL Livermore site and Site $\mathbf{3 0 0}$ 
Major population centers near Livermore include the nearby communities of Pleasanton and Tracy, and the more distant metropolitan areas of Oakland, San Jose, and San Francisco, as well as Stockton in the San Joaquin Valley. Site 300, LLNL's Experimental Test Site, is located 12 miles (20 km) east of the Livermore site in the Altamont hills of the Diablo Range; it occupies an area of 11.8 square miles $\left(30.3 \mathrm{~km}^{2}\right)$. Much of the surrounding area is in agricultural use, primarily as grazing land for cattle and sheep. The nearest residential area is the town of Tracy, located 6 miles (10 km) to the northeast.

\subsection{Regional Climate}

The lowlands in California, including the Livermore area, are classified as a dry-summer or Mediterranean climate according to the Köppen system (Ahrens 2003). Mild, wet winters and mild-tohot dry summers as a result of the migration of the semi-permanent subtropical high-pressure system over the eastern Pacific Ocean characterize the climate. The high-pressure system extends northward in the summer and forces eastward-moving storms to travel well north of California, thereby causing little or no precipitation to fall for five or six consecutive months. The infrequent rains that do occur during the dry season are caused by a northward surge of tropical moisture resulting in brief showers or even thundershowers. The high-pressure system recedes toward the equator during the winter, allowing the westerly winds to transport moisture-laden storms across the area.

The varying terrain has a large effect on precipitation amounts and patterns. Precipitation is greatest on windward sides of mountains and hills while dry "rain shadows" occur on the lee sides. Thunderstorms occur infrequently and can be accompanied with hail during the strongest storms. Thunderstorms and lightning are somewhat more common at Site 300 than at the Livermore site because of its higher altitude. Snowfall is so rare and falls in such small amounts at the Livermore site that it can be disregarded as a climatic feature. Snowfall occurs somewhat more frequently at Site 300 and snowfalls of several inches occur a few times a year on nearby hills at elevations above approximately 2,000 feet ( $\sim 00 \mathrm{~m})$. The last significant snowfall in Livermore occurred on February 5, 1976 when a few inches accumulated on grassy surfaces. ${ }^{1}$

Dense fog that results from overnight radiational cooling near the ground occurs frequently in Livermore during winter mornings when the soil is wet, skies are clear, and winds are light. These conditions are especially common in the San Joaquin Valley to the east. While conditions are less ideal for fog to form at Site 300, the fog can fill up deeply in the San Joaquin Valley and shroud Site 300 for several days at a time and sometimes spill westward through the Altamont Pass and affect the Livermore site. Advection fog that forms over the cold summer waters offshore on the Pacific Ocean occasionally gets transported to the Livermore site overnight or during mornings.

\subsection{Regional Topography and Rainfall}

The Livermore site is located in the southeastern portion of the Livermore Valley that is oriented in an east-west direction within the Diablo Range of the California Coast Range. The Livermore Valley is bounded on the west by Pleasanton Ridge and on the east by the Altamont hills. Figure 1.2 shows an aerial photograph indicating the location of the rain gauge (and meteorological tower) at the Livermore

\footnotetext{
${ }^{1}$ Personal correspondence with Ron Hafner, Livermore Cooperative Weather Observer, August 25, 2006.
} 


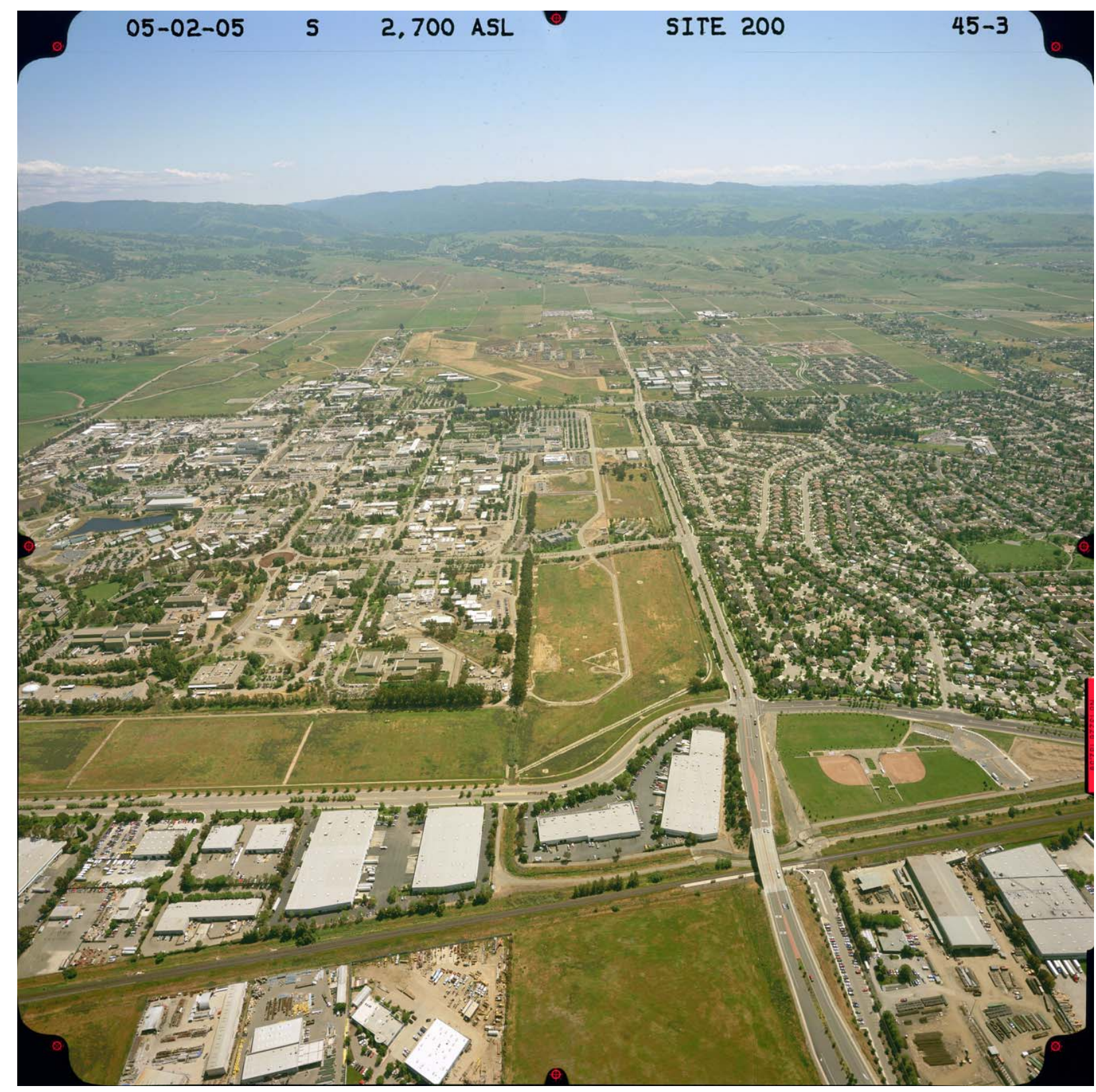

Figure 1.2. Aerial view looking toward the south showing the Livermore meteorological tower and rain gauge site and surrounding area. The tower and rain gauge are located in an open field within the triangle slightly below the center of the picture.

site and surrounding area. Note the Livermore hills in the background (i.e., toward the south). The rain gauge location is also shown on a map (Appendix A) and location statistics are shown in Appendix C.

The topography of Site 300 is much more irregular than that of the Livermore site. A series of steep hills and ridges is oriented along a generally northwest-southeast direction and is separated by intervening ravines. The Altamont hills, where Site 300 is located, are part of the California Coast Range and separate the Livermore Valley to the west from the San Joaquin Valley to the east. The elevation ranges from approximately 1,765 feet $(538 \mathrm{~m})$ above sea level at the northwestern corner of the site to approximately 490 feet $(150 \mathrm{~m})$ in the southeast portion. A picture of the Site 300 rain gauge (this model was installed in January 2005) and nearby hills to the south is shown in Figure 1.3. The 
rain gauge location at Site 300 is also shown on a map (Appendix B) and location statistics are shown in Appendix C.

Appendix D includes a table showing rain gauge history and estimated accuracy along with discussions of possible measurement errors. LLNL rainfall records start in early 1958 and were taken from a southwestern location at the Lab. An automatic rain gauge (tipping bucket) was installed for rainfall measurements at the meteorological tower in the northwestern buffer zone in September 1989. Similar average rainfall is expected at the two sites because they are within one mile of each other, even though rainfall can occasionally differ significantly over small distances during brief showers. Site 300 rainfall records start in September 1959 and a tipping bucket was installed in December 1988. The entire record of rainfall measurements at Site 300 is from the same general area

The automatic tipping bucket rain gauges at both the Livermore site and Site 300 have supplied continuous 15-minute rainfall totals since the tipping bucket installations. The use of manual accumulation rainfall gauges required an observer to estimate the total rainfall since the last time the gauge was emptied. The rain gauge was checked daily during workdays (most weekdays) except for holidays. While these manual observations were made with adequate accuracy, precise daily or hourly rainfalls could not be determined. Therefore while monthly, seasonal, and annual analyses are shown in this report since 1958 and 1959 for the Livermore site and Site 300, respectively, the daily and short-term analyses can only be presented for data collected after the tipping buckets were installed.

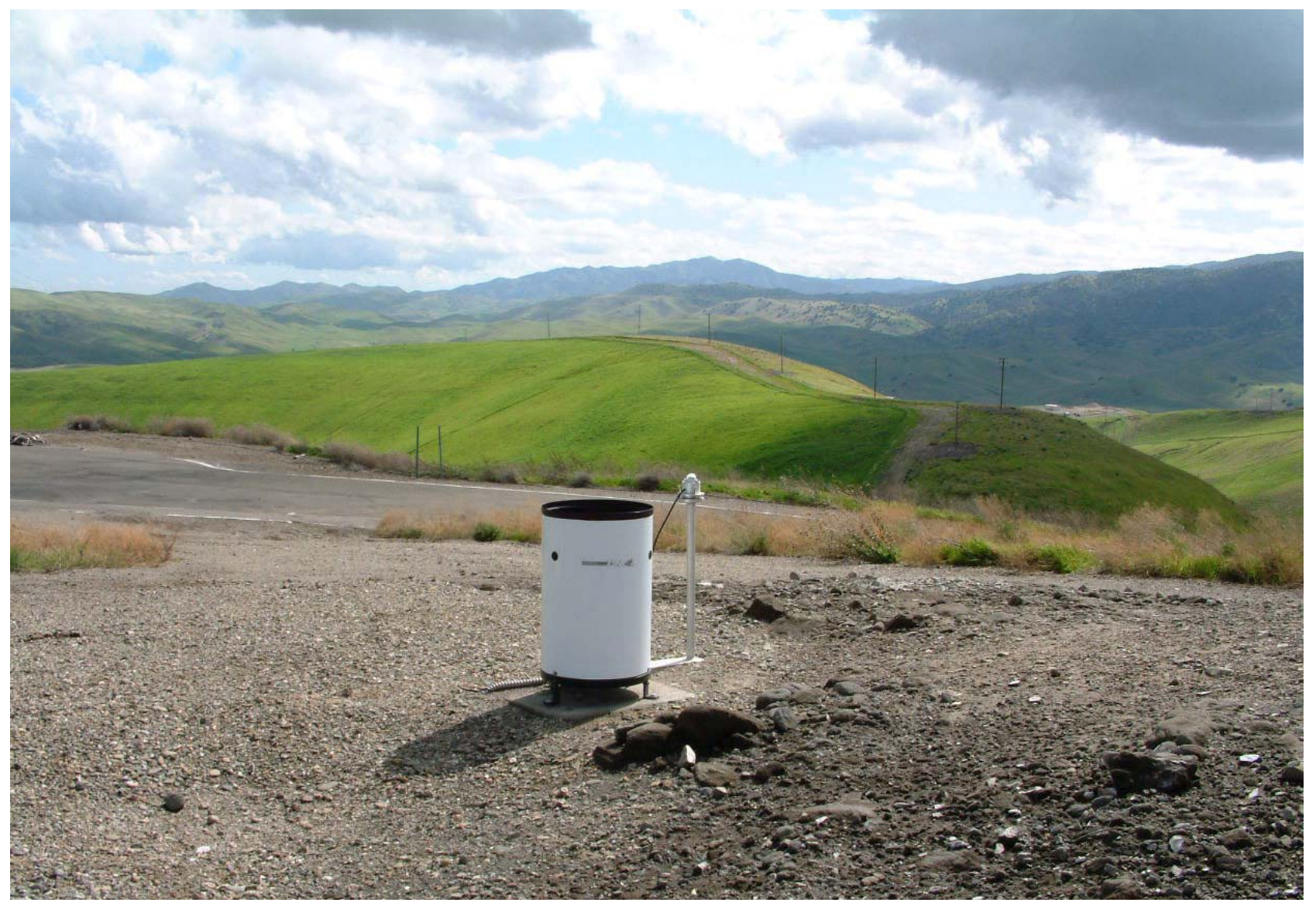

Figure 1.3. View toward the south-southeast of the Site 300 rain gauge (Photo by Gary Bear) 
The effect of the region's varying terrain on precipitation is clearly seen in Figure 1.4. The terrain and annual precipitation normals (1971-2000) are based on maps downloaded from the Prism Group's ${ }^{2}$ Web page (http://www.ocs.orst.edu/prism/). Annual precipitation reaches over 50 inches along the coastal hills of the Pacific coast. A secondary maximum of about 30 inches is evident over the hills south of Livermore. The higher terrain receives more precipitation as southerly to southwesterly winds are forced up over the high terrain during storms, thereby cooling the air that results in enhanced condensation and precipitation. As the air descends down the elevated terrain, the air warms and dries out, thereby causing "rain shadows" in the lee of the higher terrain. Note the large rain shadow with about 10 inches of annual rainfall that extends in the San Joaquin valley from Tracy to the southeast. This rain shadow extends for a long distance since typical southwesterly winds must travel large distances over higher terrain. A secondary precipitation minimum can be seen in the valley northwest of San Jose (Santa Clara Valley) in the lee of coastal hills. The rain shadow effect is strongest immediately downwind of higher terrain and lessens further downwind. For instance, precipitation increases from Tracy northward to Stockton and farther to the north.

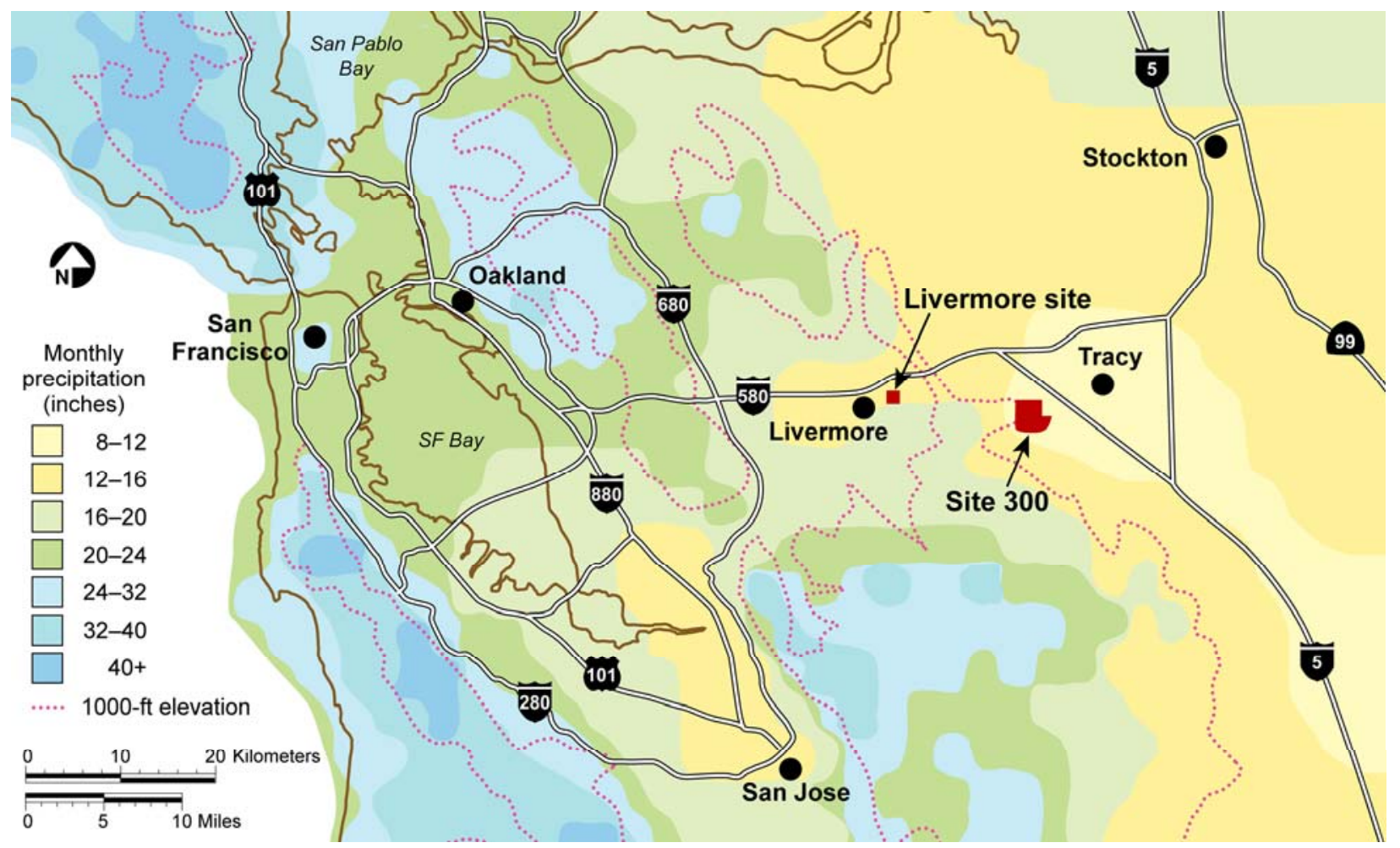

Figure 1.4. Map showing regional terrain above 1000 feet above sea level and annual normal (1971-2000) precipitation. (Map created August 29, 2006 with data downloaded from ocs.orst.edu/prism/. Copyright $\odot$ 2005, PRISM Group, Oregon State University)

\footnotetext{
2 The PRISM model is a knowledge-based modeling system that uses point measurements of precipitation and other variables. PRISM is unique in that it incorporates expert knowledge of "rain shadows."
} 
The Livermore Valley receives between 12 and 16 inches of rain annually on average. Note that precipitation increases to the south, west, and north of LLNL. Measurements from the National Weather Service's Cooperative Observer Program (COOP) at Livermore indicate that annual rainfall increases by approximately one inch about 2.5 miles ( $4 \mathrm{~km})$ west of LLNL's Livermore site. The normal monthly and most recent seasonal rainfall at the Livermore COOP site can be seen at the following Web link: http://www.wrcc.dri.edu/cgi-bin/cliMAIN.pl?ca4997. Precipitation measurements at Site 300 demonstrate a decrease in annual precipitation of about 3 inches. Detailed comparisons of rainfall at LLNL's Livermore site and Site 300 are discussed in detail in the following sections.

\section{PRECIPITATION (RAINFALL)}

\subsection{Monthly precipitation normals and medians}

Monthly normal ${ }^{3}$ rainfalls based on the 30-year period from 1971 to 2000 are shown in Figure 2.1. Table 2.1 shows the normals (means) along with monthly medians. Most rain falls during the cold season, with monthly rainfall reaching a peak in January. If the months are normalized for the number of days, February is actually the rainiest month and receives slightly more precipitation than January at both sites. Approximately 55 percent of the seasonal rain at both sites falls in January, February, and March and approximately 82 percent and 79 percent of the rain falls in the five months from November through March at the Livermore site and Site 300, respectively. Rainfall is scant at both sites during the summer months, with less than two percent of the seasonal rain falling from June through August. Site 300 receives about 78 percent of the annual amount of precipitation that falls at the Livermore site. Site 300 has a longer fetch of higher terrain to the south and southwest, thereby creating a more pronounced rain shadow effect during winter storms when winds are frequently southerly to southwesterly. Note that in the warm season, the rainfall amounts are nearly equal or actually greater at Site 300 (e.g., May) when local convection or showers occur more readily over higher terrain and a strong southerly to southwesterly wind flow is less frequent.

All of the monthly and annual medians are less than the normals based on 30-yr periods as shown in Table 1. This results from rainfall being skewed toward wet months and years (i.e., a few heavy rainfalls in individual months or years inflates the normals or means relative to the medians). Therefore the median is a better indicator of "typical” rainfall than the normal. The annual median rainfall at both sites is slightly less than 90 percent of the normal. The monthly median values indicate that summer months at the Livermore site and two summer months at Site 300 typically receive no measurable precipitation.

\footnotetext{
${ }^{3}$ Normals are 30-year means of climate variables such as rainfall and temperature. By convention, the current normal is based on the latest 30-year period ending with the most recent decade. The use of fixed 30-year normals prevents confusing year-to-year changes but does incorporate long-term trends.
} 


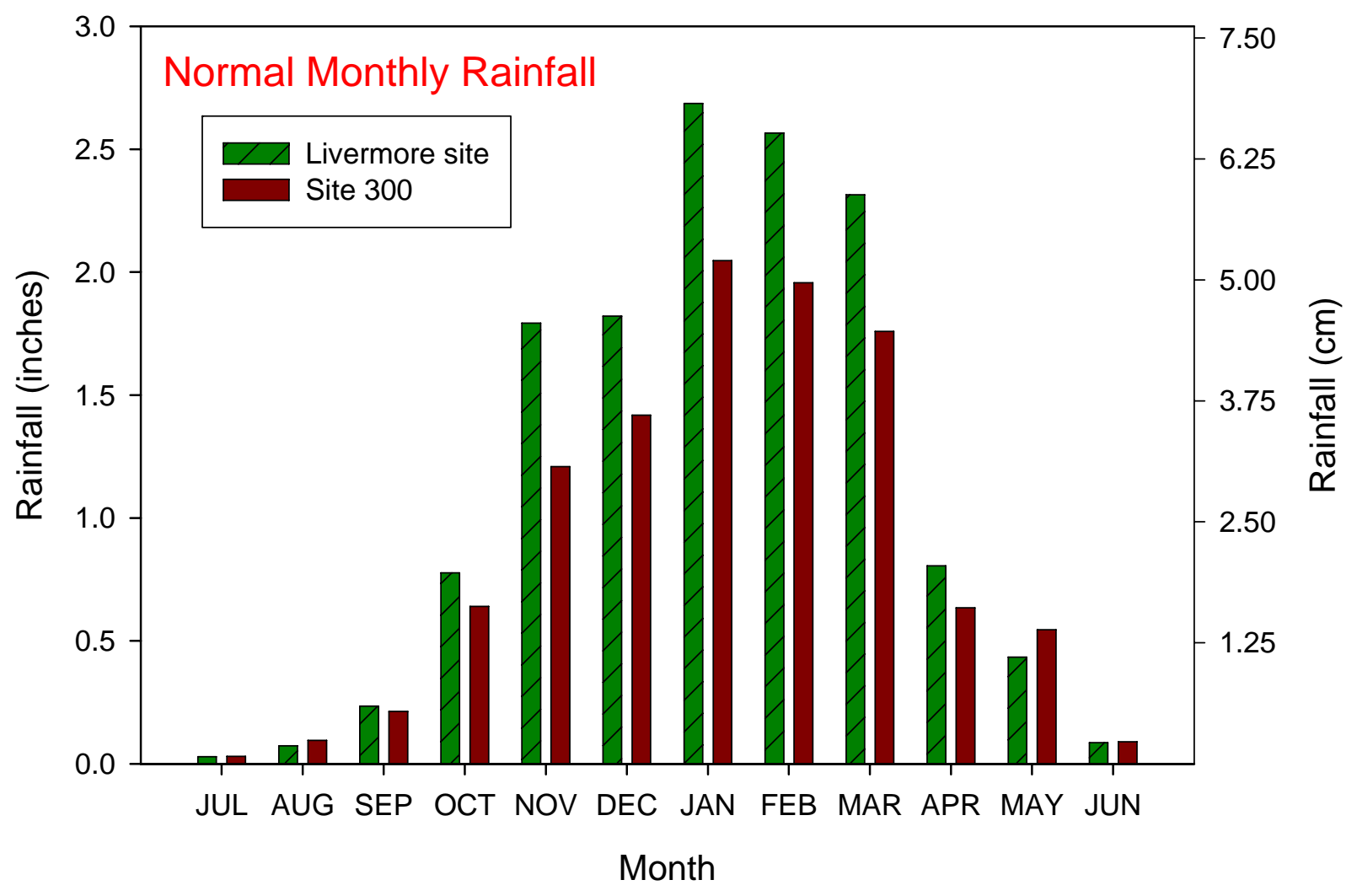

Figure 2.1. Livermore site and Site 300 normal monthly precipitation for 1971-2000.

Table 2.1. Livermore site and Site $\mathbf{3 0 0}$ monthly and annual precipitation normals and medians (1971-2000) in inches.

\begin{tabular}{l|cc|cc}
\hline \multirow{2}{*}{ Month } & \multicolumn{2}{|c|}{ Normal } & \multicolumn{2}{c}{ Median } \\
\cline { 2 - 5 } & Livermore & Site 300 & Livermore & Site $\mathbf{3 0 0}$ \\
\hline January & 2.69 & 2.05 & 1.95 & 1.65 \\
February & 2.57 & 1.96 & 2.55 & 1.65 \\
March & 2.32 & 1.76 & 2.13 & 1.74 \\
April & 0.81 & 0.64 & 0.63 & 0.50 \\
May & 0.43 & 0.55 & 0.17 & 0.05 \\
June & 0.09 & 0.09 & 0.00 & 0.01 \\
July & 0.03 & 0.03 & 0.00 & 0.00 \\
August & 0.07 & 0.10 & 0.00 & 0.00 \\
September & 0.23 & 0.21 & 0.05 & 0.02 \\
October & 0.78 & 0.64 & 0.68 & 0.61 \\
November & 1.79 & 1.21 & 1.32 & 0.79 \\
December & 1.82 & 1.42 & 1.65 & 1.27 \\
ANNUAL & 13.62 & 10.64 & 11.92 & 9.27 \\
\hline
\end{tabular}




\subsection{Precipitation probabilities}

Livermore site and Site 300 precipitation probabilities were calculated by month, year, rainfall season, and season and are presented in Tables 2.2 and 2.3. These data can aid planners, designers, or experimenters to determine probabilities that a specific precipitation amount is equaled or exceeded during a given time period. Because the Livermore site typically has greater rainfall, most probabilities have higher associated precipitation amounts at this site than at Site 300. The exceptions are for the lowest probabilities in the final two months of the year and the highest probabilities during the middle of the year. The higher rainfall amounts associated with the higher probabilities in the warm season likely result from more frequent shower activity over the higher terrain near Site 300.

\subsection{Number of days with precipitation exceeding specified amounts}

The mean and median number of days with precipitation that exceeds specified amounts, the maximum number of days recorded, and the year of its occurrence were calculated for the Livermore site and Site 300 and are listed in Tables 2.4 and 2.5. Note that the greatest number of days that exceed specified precipitation amounts typically occurs in the months of January and February, followed by December and March. The lone exception is at the Livermore site where the highest average number of days that exceed 1 inch occurs in March. Likewise the maximum number of days with precipitation that exceeds the specified amounts occurs during the months of January, February, or March at both sites.

The difference between the minimum and maximum number of days exceeding the specified precipitation amounts reflects the year-to-year variation. The ratio of maximum to minimum number of days exceeding the threshold during the rainfall season increases from approximately 2.4 for the 0.01-inch threshold to nearly 3.7 for the 0.25 -inch threshold at the Livermore site and increases from just under 2.5 for 0.01 inches to just over 4 for the 0.25 -inch threshold at Site 300 .

The number of days exceeding specific thresholds is greater at the Livermore site than at Site 300 for most periods. The fraction of mean number of days exceeding the threshold at Site 300 compared to the Livermore site during the year and rainfall season increases from only 1.05 for 0.01 inches to about 1.35 for the 0.50 -inch threshold (not shown). The ratio decreases for the heavier daily rainfalls possibly because some of them are caused by local showers and are not so dependent on the local terrain effects.

The mean number of days exceeding the specified precipitation amounts closely approximates the median number for most months with the mean usually exceeding the median. The mean exceeds the median number of days for all precipitation thresholds for the year and rainfall season. 
Table 2.2 Livermore site precipitation probabilities, 1958-2006. Column headings represent percentage of time precipitation is less than, or equal to, the specified amount for a given month, year, or season.

\begin{tabular}{|c|c|c|c|c|c|c|c|c|c|}
\hline Precipitation (in.) & Low & $5 \%$ & $10 \%$ & $25 \%$ & $50 \%$ & $75 \%$ & $90 \%$ & $95 \%$ & High \\
\hline January & 0.27 & 0.31 & 0.50 & 1.25 & 2.08 & 3.88 & 5.17 & 5.74 & 7.06 \\
\hline February & 0.07 & 0.21 & 0.38 & 0.95 & 2.23 & 3.59 & 4.31 & 5.37 & 7.06 \\
\hline March & 0.02 & 0.19 & 0.24 & 0.92 & 1.77 & 2.83 & 4.79 & 5.22 & 7.19 \\
\hline April & 0.03 & 0.08 & 0.15 & 0.28 & 0.74 & 1.26 & 2.54 & 3.52 & 3.72 \\
\hline May & 0.00 & 0.00 & 0.00 & 0.00 & 0.17 & 0.56 & 0.85 & 1.72 & 2.44 \\
\hline June & 0.00 & 0.00 & 0.00 & 0.00 & 0.00 & 0.12 & 0.26 & 0.41 & 0.88 \\
\hline July & 0.00 & 0.00 & 0.00 & 0.00 & 0.00 & 0.00 & 0.00 & 0.15 & 0.57 \\
\hline August & 0.00 & 0.00 & 0.00 & 0.00 & 0.00 & 0.00 & 0.16 & 0.37 & 0.89 \\
\hline September & 0.00 & 0.00 & 0.00 & 0.00 & 0.04 & 0.16 & 0.64 & 1.33 & 2.03 \\
\hline October & 0.00 & 0.00 & 0.00 & 0.07 & 0.37 & 0.98 & 1.78 & 2.12 & 3.75 \\
\hline November & 0.00 & 0.03 & 0.10 & 0.54 & 1.58 & 3.01 & 3.87 & 4.61 & 6.34 \\
\hline December & 0.06 & 0.22 & 0.26 & 0.92 & 1.84 & 2.98 & 3.78 & 5.02 & 5.21 \\
\hline Annual & 6.57 & 8.18 & 9.05 & 9.83 & 12.14 & 15.81 & 19.72 & 20.89 & 33.57 \\
\hline Rainfall Season & 5.38 & 7.10 & 8.69 & 10.07 & 11.55 & 16.54 & 19.85 & 21.62 & 30.57 \\
\hline $\begin{array}{l}\text { Winter (Dec-Feb) } \\
\text { (Season of occurrence) }\end{array}$ & $\begin{array}{c}2.20 \\
(1975-76)\end{array}$ & 2.66 & 3.54 & 5.03 & 6.66 & 8.23 & 11.79 & 13.28 & $\begin{array}{c}14.10 \\
(1995-96)\end{array}$ \\
\hline $\begin{array}{l}\text { Spring (Mar-May) } \\
\text { (Year of occurrence) }\end{array}$ & $\begin{array}{c}0.41 \\
(1997)\end{array}$ & 0.58 & 0.69 & 1.95 & 2.85 & 4.44 & 7.43 & 8.73 & $\begin{array}{c}9.89 \\
(1983)\end{array}$ \\
\hline $\begin{array}{l}\text { Summer (Jun-Aug) } \\
\text { (Year of occurrence) }\end{array}$ & $\begin{array}{c}0.00 \\
\text { (many) }\end{array}$ & 0.00 & 0.00 & 0.00 & 0.05 & 0.26 & 0.56 & 0.88 & $\begin{array}{c}0.91 \\
(1964)\end{array}$ \\
\hline $\begin{array}{l}\text { Fall (Sep-Nov) } \\
\text { (Year of occurrence) }\end{array}$ & $\begin{array}{c}0.00 \\
(1958)\end{array}$ & 0.22 & 0.57 & 1.34 & 2.30 & 3.75 & 5.49 & 7.37 & $\begin{array}{c}7.54 \\
(1983)\end{array}$ \\
\hline
\end{tabular}

Table 2.3. Site 300 precipitation probabilities, 1959-2006. Column headings represent percentage of time precipitation is less than, or equal to, the specified amount for a given month, year, or season.

\begin{tabular}{|c|c|c|c|c|c|c|c|c|c|}
\hline Precipitation (in.) & Low & $5 \%$ & $10 \%$ & $25 \%$ & $50 \%$ & $75 \%$ & $90 \%$ & $95 \%$ & High \\
\hline January & 0.14 & 0.31 & 0.48 & 0.77 & 1.75 & 3.07 & 4.11 & 4.35 & 5.43 \\
\hline February & 0.04 & 0.20 & 0.30 & 0.54 & 1.39 & 2.79 & 3.71 & 3.91 & 6.54 \\
\hline March & 0.01 & 0.08 & 0.15 & 0.58 & 1.40 & 2.10 & 3.20 & 3.71 & 5.36 \\
\hline April & 0.00 & 0.06 & 0.11 & 0.25 & 0.55 & 1.23 & 1.61 & 1.99 & 2.67 \\
\hline May & 0.00 & 0.00 & 0.00 & 0.01 & 0.08 & 0.47 & 0.91 & 2.02 & 4.23 \\
\hline June & 0.00 & 0.00 & 0.00 & 0.00 & 0.00 & 0.08 & 0.28 & 0.54 & 0.69 \\
\hline July & 0.00 & 0.00 & 0.00 & 0.00 & 0.00 & 0.00 & 0.11 & 0.21 & 0.51 \\
\hline August & 0.00 & 0.00 & 0.00 & 0.00 & 0.00 & 0.00 & 0.37 & 0.95 & 1.45 \\
\hline September & 0.00 & 0.00 & 0.00 & 0.00 & 0.02 & 0.10 & 0.43 & 1.45 & 1.96 \\
\hline October & 0.00 & 0.00 & 0.00 & 0.06 & 0.37 & 0.84 & 1.60 & 1.70 & 2.52 \\
\hline November & 0.00 & 0.08 & 0.13 & 0.44 & 0.98 & 1.86 & 3.00 & 3.73 & 4.66 \\
\hline December & 0.12 & 0.16 & 0.22 & 0.68 & 1.45 & 2.05 & 3.36 & 3.82 & 4.33 \\
\hline Annual & 5.61 & 5.89 & 6.71 & 7.78 & 9.75 & 12.00 & 17.03 & 17.29 & 23.58 \\
\hline Rainfall Season & 3.82 & 5.98 & 6.61 & 7.78 & 9.17 & 13.12 & 15.26 & 16.38 & 23.64 \\
\hline Winter (Dec-Feb) & 1.23 & 2.29 & 2.77 & 3.81 & 5.07 & 6.19 & 9.22 & 10.61 & 11.98 \\
\hline (Season of occurrence) & $(1976-77)$ & & & & & & & & (1996) \\
\hline $\begin{array}{l}\text { Spring (Mar-May) } \\
\text { (Year of occurrence) }\end{array}$ & $\begin{array}{c}0.30 \\
(2004)\end{array}$ & 0.47 & 0.70 & 1.50 & 2.35 & 3.67 & 5.30 & 6.51 & $\begin{array}{c}7.01 \\
(1983)\end{array}$ \\
\hline Summer (Jun-Aug) & 0.00 & 0.00 & 0.00 & 0.00 & 0.05 & 0.28 & 0.77 & 0.99 & 1.45 \\
\hline (Year of occurrence) & (many) & & & & & & & & (1968) \\
\hline Fall (Sep-Nov) & 0.27 & 0.37 & 0.46 & 0.92 & 1.83 & 2.85 & 3.94 & 5.03 & 6.88 \\
\hline (Year of occurrence) & (1990) & & & & & & & & (1982) \\
\hline
\end{tabular}


Table 2.4. Livermore site mean and median number of days of precipitation for specified amounts, maximum number of days in which rainfall exceeded the specified amount, and latest year in which the maximum occurred. The period of record is 1989-2006. An asterisk denotes latest year for multiple occurrences.

\begin{tabular}{|c|c|c|c|c|c|c|c|c|c|c|c|c|c|c|c|c|}
\hline & \multicolumn{4}{|c|}{0.01 in. } & \multicolumn{4}{|c|}{0.05 in. } & \multicolumn{4}{|c|}{0.10 in } & \multicolumn{4}{|c|}{0.25 in. } \\
\hline & Mean & (Med.) & Max & (Year) & Mean & (Med.) & Max & (Year) & Mean & (Med) & Max & (Year) & Mean & (Med.) & Max & (Year) \\
\hline January & 11.7 & $(11.0)$ & 24 & (1995) & 7.8 & (6.0) & 20 & (1995) & 6.1 & (6.0) & 17 & (1995) & 3.8 & (3.0) & 8 & (1995) \\
\hline February & 11.0 & $(13.0)$ & 20 & (1998) & 7.9 & (9.0) & 15 & (1998) & 6.5 & (8.0) & 13 & (1998) & 3.4 & (4.0) & 11 & (1998) \\
\hline April & 5.9 & (5.0) & 13 & (2006) & 3.7 & (3.0) & 8 & $(2006)^{\star}$ & 2.8 & (2.0) & 8 & (2006) & 1.4 & (1.0) & 5 & (2003) \\
\hline May & 3.6 & (3.0) & 12 & (1990) & 2.7 & (2.0) & 9 & (1998) & 2.1 & (2.0) & 7 & (1998) & 0.9 & (1.0) & 4 & (1998) \\
\hline August & 0.5 & $(0.0)$ & 3 & $(2003)^{\star}$ & 0.2 & $(0.0)$ & 1 & $(2003)^{\star}$ & 0.2 & $(0.0)$ & 1 & $(2003)^{\star}$ & 0.0 & $(0.0)$ & - & - \\
\hline September & 0.8 & (1.0) & 3 & (1990) & 0.4 & $(0.0)$ & 1 & $(2005)^{\star}$ & 0.2 & $(0.0)$ & 1 & $(2005)^{\star}$ & 0.2 & $(0.0)$ & 1 & $(2005)^{\star}$ \\
\hline October & 2.6 & $(2.0)$ & 8 & $(2000)$ & 1.9 & $(2.0)$ & 6 & $(2000)$ & 1.4 & (1.0) & 5 & $(2004)^{*}$ & 0.9 & $(1.0)$ & 4 & (2000) \\
\hline November & 6.5 & (6.0) & 17 & (1997) & 4.4 & (3.5) & 13 & (1997) & 3.4 & (3.0) & 10 & (1997) & 1.7 & (2.0) & 5 & (1997) \\
\hline December & 9.4 & (8.5) & 17 & (2003) & 6.7 & (5.5) & 13 & $(2003)^{\star}$ & 5.3 & (5.0) & 13 & (2001) & 3.4 & (3.0) & 9 & (2002) \\
\hline \multirow[t]{4}{*}{$\begin{array}{l}\text { Rainfall } \\
\text { Season }\end{array}$} & 62.0 & $(56.0)$ & 104 & $\begin{array}{c}(1997- \\
98)\end{array}$ & 43.4 & $(39.0)$ & 73 & $\begin{array}{c}(1997- \\
98)\end{array}$ & 34.0 & $(30.0)$ & 58 & $\begin{array}{c}\text { (1997- } \\
98)\end{array}$ & 18.7 & $(18.0)$ & 33 & $\begin{array}{c}(1997- \\
98)\end{array}$ \\
\hline & & Min: & 36 & $\begin{array}{c}(1989- \\
90)\end{array}$ & & Min: & 25 & $\begin{array}{c}(1989- \\
90)\end{array}$ & & Min: & 22 & $\begin{array}{c}(1990- \\
91)^{\star}\end{array}$ & & Min: & 9 & $\begin{array}{c}(1989- \\
90)\end{array}$ \\
\hline & \multicolumn{4}{|c|}{0.50 in. } & \multicolumn{4}{|c|}{0.75 in. } & \multicolumn{4}{|c|}{1.00 in } & & & & \\
\hline & Mean & (Med.) & Max & (Year) & Mean & (Med.) & Max & (Year) & Mean & (Med) & Max & (Year) & & & & \\
\hline January & 1.5 & (1.0) & 4 & $(1998)^{\star}$ & 0.8 & $(1.0)$ & 3 & (1996) & 0.2 & $(0.0)$ & 1 & $(2004)^{\star}$ & & & & \\
\hline February & 1.6 & (1.0) & 5 & (1998) & 0.5 & $(0.0)$ & 2 & (1998) & 0.3 & $(0.0)$ & 1 & $(2005)^{\star}$ & & & & \\
\hline March & 1.0 & $(0.0)$ & 4 & $(1995)^{\star}$ & 0.4 & $(0.0)$ & 3 & (1995) & 0.4 & $(0.0)$ & 3 & (1995) & & & & \\
\hline November & 0.8 & $(1.0)$ & 3 & (1994) & 0.4 & $(0.0)$ & 2 & (1994) & 0.2 & $(0.0)$ & 1 & $(2002)^{\star}$ & & & & \\
\hline December & 1.4 & (1.0) & 4 & (2002) & 0.6 & $(0.0)$ & 2 & $(2005)^{\star}$ & 0.3 & $(0.0)$ & 2 & (1995) & & & & \\
\hline \multirow[t]{2}{*}{ Annual } & 7.6 & (7.0) & 15 & (1996) & 2.9 & (2.0) & 7 & $(1996)^{\star}$ & 1.5 & (1.0) & 6 & (1995) & & & & \\
\hline & & Min: & 3 & (1997) & & Min: & 1 & $(2003)^{\star}$ & & Min: & 0 & $(2006)^{\star}$ & & & & \\
\hline \multirow[t]{2}{*}{$\begin{array}{l}\text { Rainfall } \\
\text { Season }\end{array}$} & 7.7 & $(7.0)$ & 14 & $\begin{array}{c}(1995- \\
96)^{\star}\end{array}$ & 2.9 & (2.0) & 7 & $\begin{array}{c}(1995- \\
96)^{\star}\end{array}$ & 1.5 & (1.0) & 4 & $\begin{array}{c}(1995- \\
96)^{\star}\end{array}$ & & & & \\
\hline & & Min: & 3 & $\begin{array}{c}(2000- \\
01)\end{array}$ & & Min: & 0 & $\begin{array}{c}(2000- \\
01)\end{array}$ & & Min: & 0 & $\begin{array}{c}(2001- \\
02)^{\star}\end{array}$ & & & & \\
\hline
\end{tabular}


Table 2.5. Site $\mathbf{3 0 0}$ mean and median number of days of precipitation for specified amounts, maximum number of days in which rainfall exceeded the specified amount, and latest year in which the maximum occurred. The period of record is 1989-2006. An asterisk denotes latest year for multiple occurrences.

\begin{tabular}{|c|c|c|c|c|c|c|c|c|c|c|c|c|c|c|c|c|}
\hline & \multicolumn{4}{|c|}{0.01 in. } & \multicolumn{4}{|c|}{0.05 in. } & \multicolumn{4}{|c|}{0.10 in } & \multicolumn{4}{|c|}{0.25 in. } \\
\hline & Mean & (Med.) & Max & (Year) & Mean & (Med.) & Max & (Year) & Mean & (Med) & Max & (Year) & Mean & (Med.) & Max & (Year) \\
\hline January & 11.7 & (11.0) & 24 & (1995) & 6.9 & (6.5) & 17 & (1995) & 5.1 & (5.0) & 13 & (1995) & 2.7 & $(2.0)$ & 7 & (1993) \\
\hline February & 9.7 & $(10.5)$ & 18 & (1998) & 6.9 & (7.0) & 14 & (1998) & 5.3 & (5.5) & 12 & (1998) & 3.1 & $(3.0)$ & 10 & (1998) \\
\hline April & 5.3 & $(5.0)$ & 13 & (2006) & 3.2 & $(4.0)$ & 8 & (2006) & 2.4 & $(2.5)$ & 7 & (2006) & 1.0 & $(0.5)$ & 4 & (2006) \\
\hline May & 3.3 & $(2.5)$ & 13 & (1998) & 2.3 & (2.0) & 11 & (1998) & 1.8 & (2.0) & 7 & (1998) & 0.9 & $(0.5)$ & 6 & (1998) \\
\hline August & 0.3 & $(0.0)$ & 2 & (2003) & 0.1 & $(0.0)$ & 1 & $(1997)^{\star}$ & 0.0 & $(0.0)$ & - & - & 0.0 & $(0.0)$ & - & - \\
\hline September & 0.7 & $(1.0)$ & 4 & (1989) & 0.3 & $(0.0)$ & 2 & (1989) & 0.2 & $(0.0)$ & 2 & (1989) & 0.2 & $(0.0)$ & 2 & (1989) \\
\hline October & 2.7 & $(3.0)$ & 7 & (2000) & 1.6 & (1.0) & 7 & (2000) & 1.1 & (1.0) & 6 & (2000) & 0.6 & $(0.0)$ & 3 & $(2004)^{\star}$ \\
\hline November & 6.1 & (5.5) & 14 & (1995) & 3.2 & (2.5) & 8 & $(1997)^{\star}$ & 2.4 & $(2.0)$ & 8 & (1994) & 1.1 & $(1.0)$ & 3 & (1997) \\
\hline December & 9.0 & (7.5) & 18 & $(2003$ & 5.7 & (5.0) & 12 & (2001) & 4.4 & $(4.0)$ & 9 & (2002) & 2.8 & $(3.0)$ & 6 & $(2005)^{\star}$ \\
\hline \multirow[t]{4}{*}{$\begin{array}{l}\text { Rainfall } \\
\text { Season }\end{array}$} & 59.4 & $(57.0)$ & 96 & $\begin{array}{c}(1997- \\
98)\end{array}$ & 37.6 & $(33.0)$ & 61 & $\begin{array}{c}(1997- \\
98)\end{array}$ & 27.8 & (26.0) & 43 & $\begin{array}{c}(1997- \\
98)\end{array}$ & 14.6 & (13.0) & 28 & $\begin{array}{c}(1997- \\
98)\end{array}$ \\
\hline & & Min: & 39 & $\begin{array}{c}(1989- \\
90)\end{array}$ & & Min: & 25 & $\begin{array}{c}(1993- \\
94)^{*}\end{array}$ & & Min: & 17 & $\begin{array}{c}(2001- \\
02)^{\star}\end{array}$ & & Min: & 7 & $\begin{array}{l}(1999- \\
2000)\end{array}$ \\
\hline & \multicolumn{4}{|c|}{0.50 in. } & \multicolumn{4}{|c|}{0.75 in. } & \multicolumn{4}{|c|}{1.00 in } & & & & \\
\hline & Mean & (Med.) & Max & (Year) & Mean & (Med.) & Max & (Year) & Mean & (Med) & Max & (Year) & & & & \\
\hline January & 1.1 & $(0.5)$ & 4 & (1996) & 0.4 & $(0.0)$ & 3 & (1996) & 0.1 & $(0.0)$ & 1 & $(2006)^{*}$ & & & & \\
\hline February & 1.3 & $(1.0)$ & 6 & (1998) & 0.7 & $(0.5)$ & 4 & (1995) & 0.5 & $(0.0)$ & 3 & (1995) & & & & \\
\hline March & 0.7 & $(0.0)$ & 4 & (1995) & 0.1 & $(0.0)$ & 1 & $(1996)^{\star}$ & 0.1 & $(0.0)$ & 1 & (1996) & & & & \\
\hline December & 1.1 & $(1.0)$ & 4 & (1995) & 0.6 & $(0.0)$ & 3 & (2002) & 0.2 & $(0.0)$ & 1 & $(2002)^{\star}$ & & & & \\
\hline \multirow[t]{2}{*}{ Annual } & 5.6 & (5.0) & 14 & $(1998)^{*}$ & 2.5 & (2.0) & 6 & $(1996)^{\star}$ & 1.2 & (1.0) & 4 & $(1996)^{\star}$ & & & & \\
\hline & & Min: & 1 & (2003) & & Min: & 0 & (2003) & & Min: & 0 & $(2006)^{*}$ & & & & \\
\hline \multirow[t]{2}{*}{$\begin{array}{l}\text { Rainfall } \\
\text { Season }\end{array}$} & 5.8 & (5.0) & 14 & $\begin{array}{c}(1995- \\
96)\end{array}$ & 2.6 & (2.0) & 6 & $\begin{array}{c}(1995- \\
96)\end{array}$ & 1.3 & (1.0) & 3 & $\begin{array}{l}(1995- \\
96)^{\star}\end{array}$ & & & & \\
\hline & & Min: & 2 & $\begin{array}{c}(2001- \\
02)^{*}\end{array}$ & & Min: & 0 & $\begin{array}{c}(2003- \\
04)^{*}\end{array}$ & & Min: & 0 & $\begin{array}{c}(2003- \\
04)^{\star}\end{array}$ & & & & \\
\hline
\end{tabular}




\section{PRECIPITATION FREQUENCY AND EXTREME VALUE ANALYSIS}

Annual or seasonal extremes and averages of weather variables such as rainfall can be analyzed to estimate return periods $\left(T_{R}\right)$ for specific values. The return period indicates the length of time, on average, that will lapse before a given annual or seasonal rainfall amount will occur, based on the bestfit lines. The expected maximum 50- and 100-year precipitation amounts, for example, are useful for structural design and estimating excess stream run-off. Because most rain falls in the winter in the Livermore area, analyses using the rainfall seasons (July 1 to June 30) are shown rather than calendar years. Seasonal rainfall analyses were made at both sites for seasonal, monthly, and shorter durations from 15 minutes to 24 hours and one calendar day.

The precipitation frequency analyses for different rainfall durations at both sites are presented in probability plots (Figures 3.1-3.4). A special Gaussian probability scale is used on the graphs to represent cumulative probability. After the seasonal rainfall totals or the highest values for various rainfall durations during each rainfall season are ranked by each season, they are plotted for cumulative probability versus the seasonal value. Note that these analyses use the Weibull (1939) method to determine ranking: $P=m /(N+1)$, where $P$ is the cumulative probability, $N$ is the number of values, and $m$ is the ranking from 1 to $N$. A study by Makkonen (2006) points out that the Weibull formula is the most accurate and conservative of ranking methods widely used while the other methods tend to predict much longer return periods of extreme events than other methods. A best-fit line is then calculated and plotted on the graph. The data will form a straight line if the extreme value distribution is Gaussian (normal). The amount of departure from a straight line is a measure of either the nonGaussian behavior of the extreme values or the lack of data (i.e., the data set is too small). A return period scale in the figures indicates the number of years, on average, that will elapse before a given seasonal rainfall amount will recur. While this discussion emphasizes the largest rainfall amounts, return periods of extreme dry rainfall amounts can also be estimated from the figures.

The seasonal values approximate a log-normal distribution while shorter-duration rainfalls have distributions more closely approximating Gaussian distributions. Relatively long return periods of specific values, such as 50 and 100 years, can be estimated from the best-fit lines. The estimates for longer periods must be used with caution since they are based on relatively few values. It is possible that the inclusion of an additional of year with an extremely large rainfall value may significantly change the return period values. Reliability of the return-period estimates increases with the size of the data set.

Rainfall season precipitation values and the best-fit lines for the Livermore site and Site 300 are plotted in Figure 3.1. Estimated precipitation amounts based on the best-fit lines for various return periods are also listed in Table 3.1. Note that the best-fit lines closely approximate the distribution of seasonal values except for the wettest and two driest seasons. The peak values of 30.57 and 23.64 inches at the Livermore site and Site 300, which occurred during the strong El Niño rainfall season of 1992-1993, are 3 to 4 inches greater than their respective best-fit lines. The best-fit lines indicate that these peak seasonal rainfalls would be expected to occur somewhat less frequently than once for every 100 years. While the difference in return periods based on measurements and the best-fit line for the highest values is reasonable based on the number of years in the sample and inherent uncertainty, planners using these data may want to be conservative and assume that the measured peak value better 
represents the approximate 50-year return period instead of the best-fit line. Finally, the best-fit lines of the two sites indicate that the ratio of Site 300 to Livermore site rainfall values is relatively constant and varies from about 0.78 to 0.80 for all return periods.

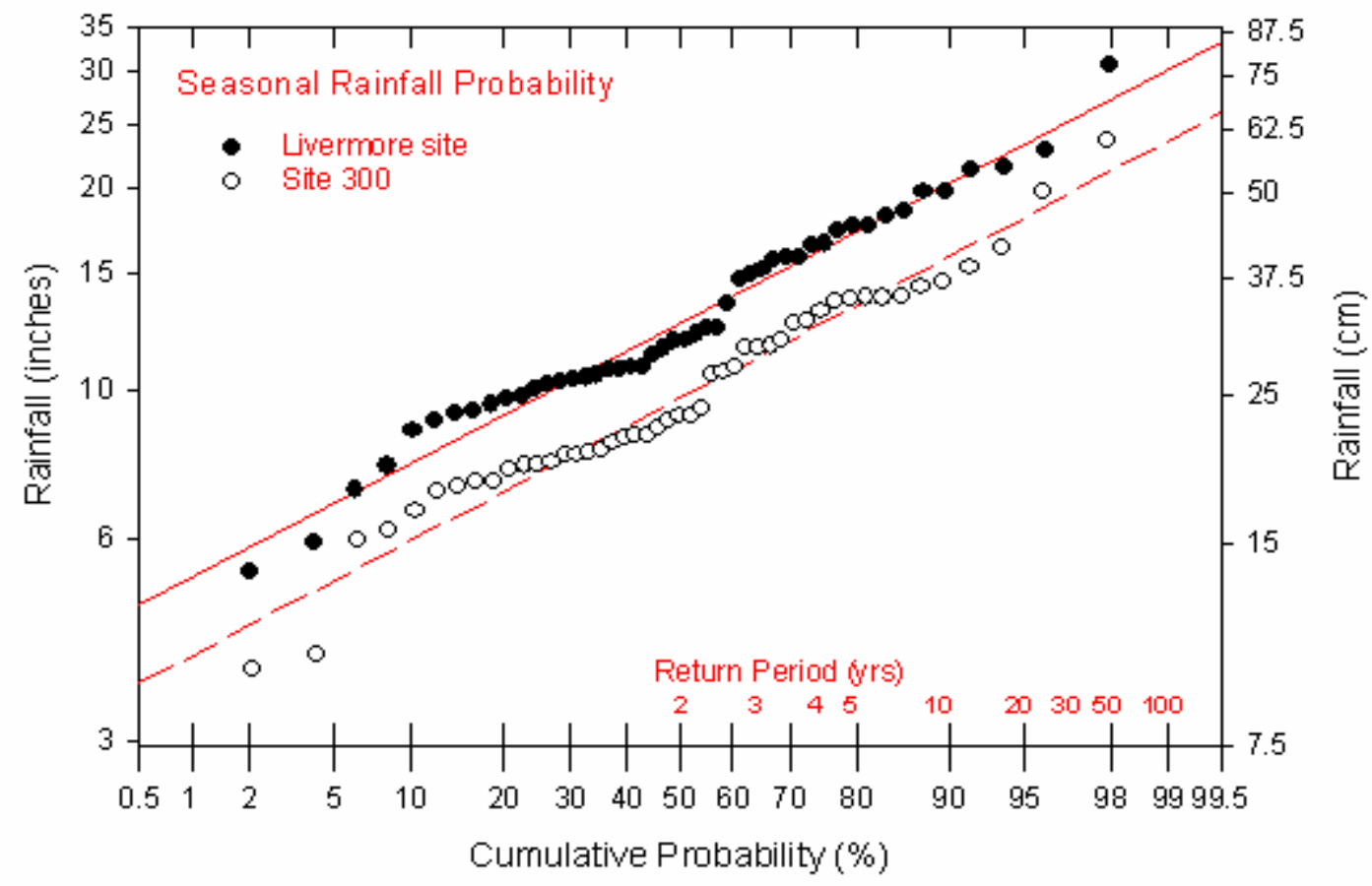

Figure 3.1. Seasonal extreme precipitation analysis for the Livermore site (1958-1959 through 2005-2006) and Site 300 (1959-1960 through 2005-2006).

Table 3.1 Estimated precipitation for various return periods and time periods at the Livermore site and Site 300. The return periods and analyses are based on rainfall seasons (July 1 through June 30).

\begin{tabular}{|c|c|c|c|c|c|c|c|c|c|c|c|}
\hline \multicolumn{12}{|c|}{ Precipitation (in.) } \\
\hline $\mathrm{T}_{\mathrm{R}}(\mathrm{yr})$ & $15 \min$ & $30 \mathrm{~min}$ & $1 \mathrm{~h}$ & $2 \mathrm{~h}$ & $3 \mathrm{~h}$ & $6 \mathrm{~h}$ & $12 \mathrm{~h}$ & $24 \mathrm{~h}$ & Day & Month & Season \\
\hline \multicolumn{12}{|c|}{ Livermore site } \\
\hline 2 & 0.18 & 0.27 & 0.40 & 0.61 & 0.72 & 0.93 & 1.16 & 1.46 & 1.25 & 4.26 & 12.53 \\
\hline 5 & 0.21 & 0.31 & 0.48 & 0.71 & 0.85 & 1.13 & 1.45 & 1.83 & 1.63 & 5.47 & 17.19 \\
\hline 10 & 0.23 & 0.33 & 0.52 & 0.76 & 0.92 & 1.23 & 1.60 & 2.03 & 1.82 & 6.11 & 20.29 \\
\hline 25 & 0.25 & 0.35 & 0.56 & 0.81 & 0.99 & 1.34 & 1.76 & 2.24 & 2.03 & 6.79 & 23.74 \\
\hline 50 & 0.26 & 0.37 & 0.59 & 0.85 & 1.04 & 1.41 & 1.87 & 2.37 & 2.17 & 7.22 & 27.19 \\
\hline 100 & 0.27 & 0.38 & 0.61 & 0.88 & 1.08 & 1.47 & 1.96 & 2.49 & 2.29 & 7.62 & 30.06 \\
\hline \multicolumn{12}{|l|}{ Site 300} \\
\hline 2 & 0.16 & 0.27 & 0.40 & 0.53 & 0.62 & 0.83 & 1.00 & 1.31 & 1.10 & 3.21 & 9.70 \\
\hline 5 & 0.20 & 0.33 & 0.50 & 0.64 & 0.75 & 1.06 & 1.27 & 1.64 & 1.38 & 4.14 & 13.40 \\
\hline 10 & 0.23 & 0.37 & 0.55 & 0.70 & 0.83 & 1.17 & 1.42 & 1.81 & 1.53 & 4.62 & 15.87 \\
\hline 25 & 0.25 & 0.40 & 0.60 & 0.76 & 0.90 & 1.30 & 1.57 & 1.99 & 1.68 & 5.14 & 19.01 \\
\hline 50 & 0.26 & 0.43 & 0.64 & 0.80 & 0.95 & 1.38 & 1.67 & 2.11 & 1.78 & 5.48 & 21.35 \\
\hline 100 & 0.28 & 0.45 & 0.67 & 0.84 & 1.00 & 1.45 & 1.75 & 2.22 & 1.87 & 5.78 & 23.72 \\
\hline
\end{tabular}


Peak monthly rainfall amounts were ranked by rainfall season and are plotted in Figure 3.2 along with the best-fit lines for each site. Note that the monthly analyses and the following shorter-term analyses use a linear scale (i.e., linear normal distribution). Both best-fit lines closely approximate the respective distributions except for the peak monthly rainfall at Site 300 that is approximately one inch greater than the best-fit line. The peak monthly rainfall values of 7.06 and 6.54 inches at the Livermore site and Site 300 both occurred in February of 1998 during another El Niño. The ratio of Site 300 to Livermore site monthly rainfalls based on the best-fit lines and the average of measured values is approximately 0.76 .

Extreme rainfalls and best-fit lines for shorter periods at the Livermore site and Site 300 are shown in Figures 3.3 and 3.4, respectively. Note that all time periods except for one day are based on running totals ending on each 15-minute period. For example, individual periods (i.e., 15 minutes through 24 hours in duration) were calculated for periods ending at 00:15, 00:30, 00:45, etc. until 24:00 for all days. Note that the peak 24-hour rainfalls are greater than peak calendar day (labeled as “1 day”) rainfalls since they are based on the greatest rainfall over 24 consecutive hours ending at any 15minute period.

The best-fit lines represent the short-term rainfall peaks reasonably well for most rainfall durations, indicating a near-normal distribution. The largest departures from a normal distribution at the Livermore site occur for the 6- and 12-hour rainfalls. The distributions agree even better with the bestfit lines at Site 300, although the largest one-hour rainfall strongly deviates from the best-fit line and nearly equals the peak 3-hour rainfall. Note that year-to-year variation in the peak rainfall amounts increases as the rainfall duration increases as indicated by the increased slope of the best-fit lines at both sites.

A comparison of the best-fit lines (and peak seasonal values) between the two sites shows that Site 300 rainfall values for the various return periods are nearly equal for the 15-minute duration and equal to or slightly larger for the 30- and 60-minute durations for return periods of at least 5 years. As mentioned previously, the higher elevation at Site 300 encourages formation of showers at that site during unstable conditions. Isolated showers tend to cause brief rainfalls that typically last for an hour or less. The Livermore site values become slightly larger than those from Site 300 for durations exceeding one hour. The ratio of Livermore site to Site 300 rainfalls (not shown) for all return periods increases slightly from about one for 15 -minute periods to about 1.12 for the 24 -hour periods and 1.20 for oneday periods.

Return periods from 2 to 100 years are listed in Table 3.1 for various precipitation durations at the Livermore site and Site 300. The monthly and seasonal return periods are based on a greater number of years and therefore are the most reliable. However, the shorter durations, based on only 16 years of data, appear to be consistent. Because all the values in Table 3.1 are based on fixed measurement times ending every 15 minutes, they will underestimate the true precipitation values for the shortest periods since maximum precipitation amounts usually straddle fixed measurement intervals. A study by Reneau (2003) uses probability theory and suggests applying the following conversion factors to adjust fixed-interval to true precipitation: 1.14 for 15 minutes, 1.07 for 30 minutes, 1.03 for one hour, and 1.01 for three hours. The 1.14 factor for 15 minutes can also be used to adjust daily periods to 24-hour 
periods. The ratios of daily to 24-hour rainfall from this study do indeed agree rather well with this suggested conversion factor: the 24-hour/daily ratios vary from 1.17 for the 2-year return period to 1.09 for the 100-year return period at the Livermore site and approximately 1.19 for all return periods at Site 300.

The 6- and 24-hour precipitation totals for the 2- and 100-year return periods shown in Table 3.1 are considerably less than those estimated from the NOAA Atlas 2 (NOAA, 1973) for both sites. NOAA Atlas 2 is a precipitation frequency atlas of the western United States that includes return period estimates for 6- and 24-hour duration precipitation durations over Northern California. The 6- and 24hour precipitation values for the 2-year return period from the atlas are 1.17 and 1.97 inches at the Livermore site, or 26 percent and 35 percent larger than those in Table 3.1. The 6- and 24-hour values from the atlas for Site 300 for the same return period are 0.99 and 1.57 inches, or 19 percent and 20 percent above the values shown in Table 3.1. The NOAA atlas overestimates even more for the 100-year return period by reporting 6- and 24-hour precipitation values of 2.52 and 4.56 inches at the Livermore site, or $71 \%$ and $82 \%$ above the 6- and 24-hour values shown in Table 3.1, respectively. The NOAA atlas likewise overestimates the 100 -year return period rainfall at Site 300 by reporting 6 - and 24-hour precipitation values of 1.99 and 4.00 inches, or $37 \%$ and $80 \%$ above the 6 - and 24-hour values shown in Table 3.1, respectively. The NOAA atlas overestimation is probably caused by the lack of reporting stations east of the Livermore region (i.e., reporting stations with higher rainfall west of Livermore skew the calculated precipitation toward high values). Therefore rainfall amounts for different return periods from Table 3.1 should be used for planning at the Livermore site and Site 300 instead of NOAA Atlas 2 estimates or values calculated from distant reporting stations.

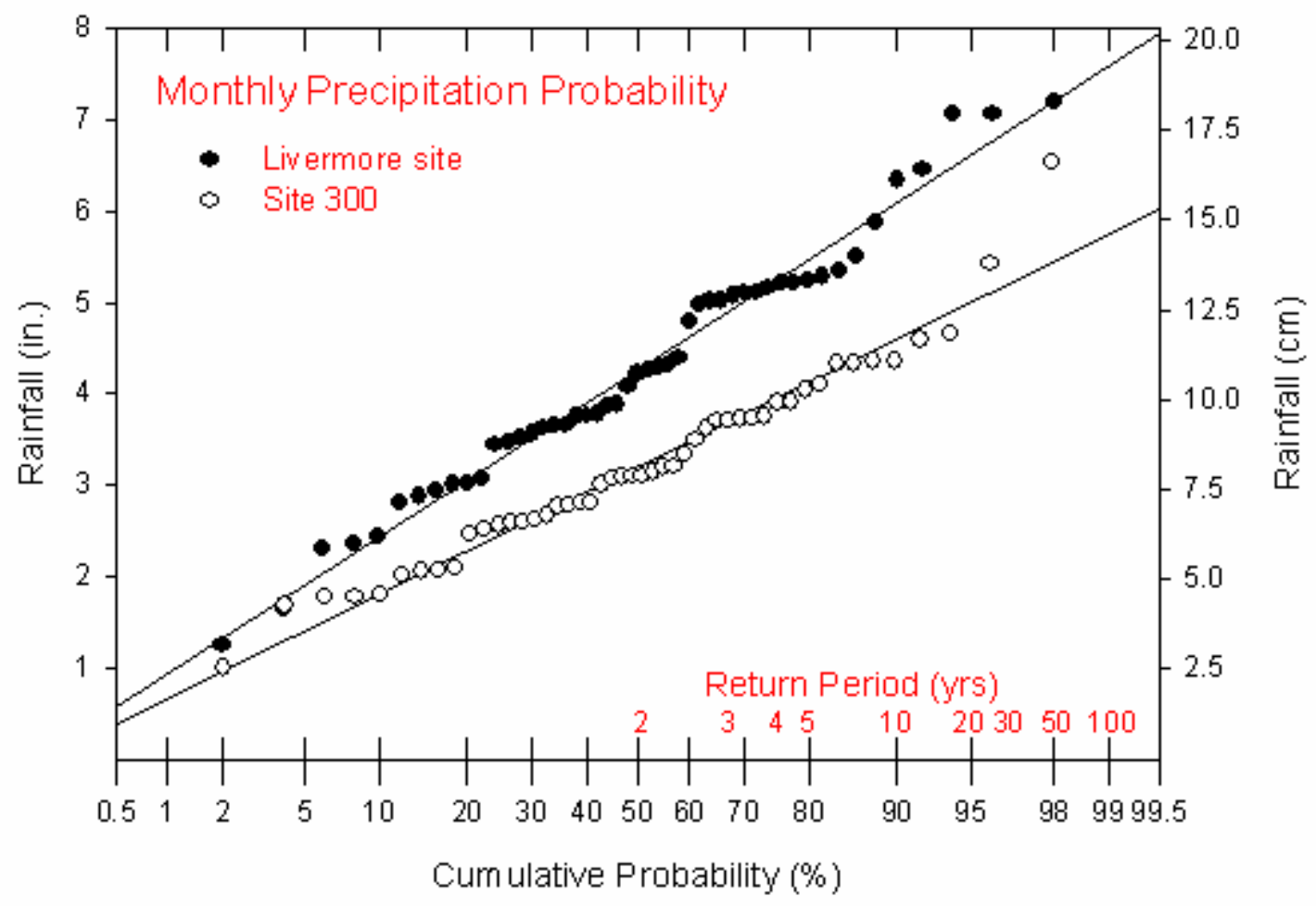

Figure 3.2. Monthly extreme precipitation analysis for the Livermore site (1958-1959 through 2005-2006) and Site 300 (1959-1960 through 2005-2006). 


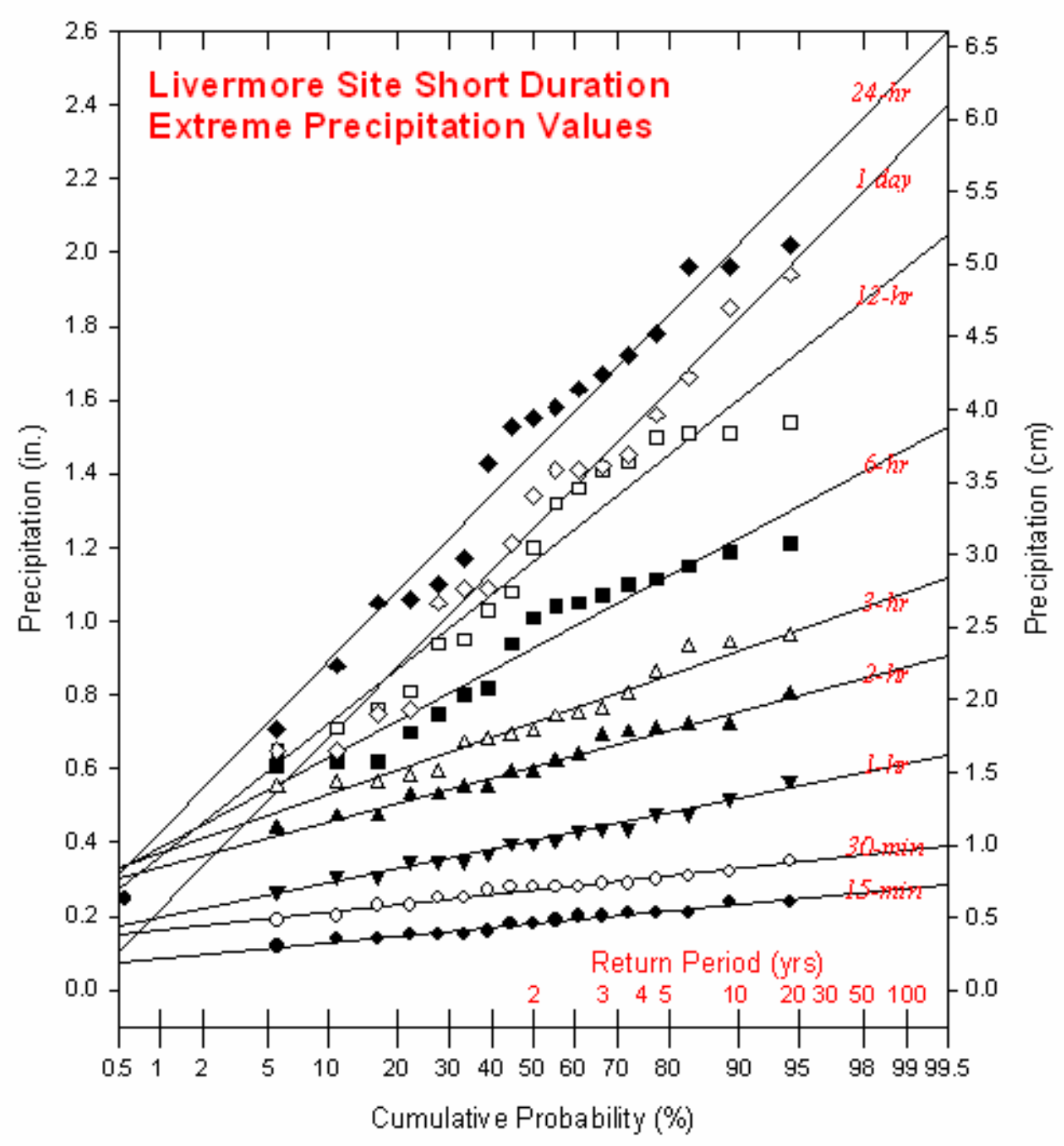

Figure 3.3. Short duration extreme precipitation analysis for the Livermore site (1989-1990 through 2005-2006). 


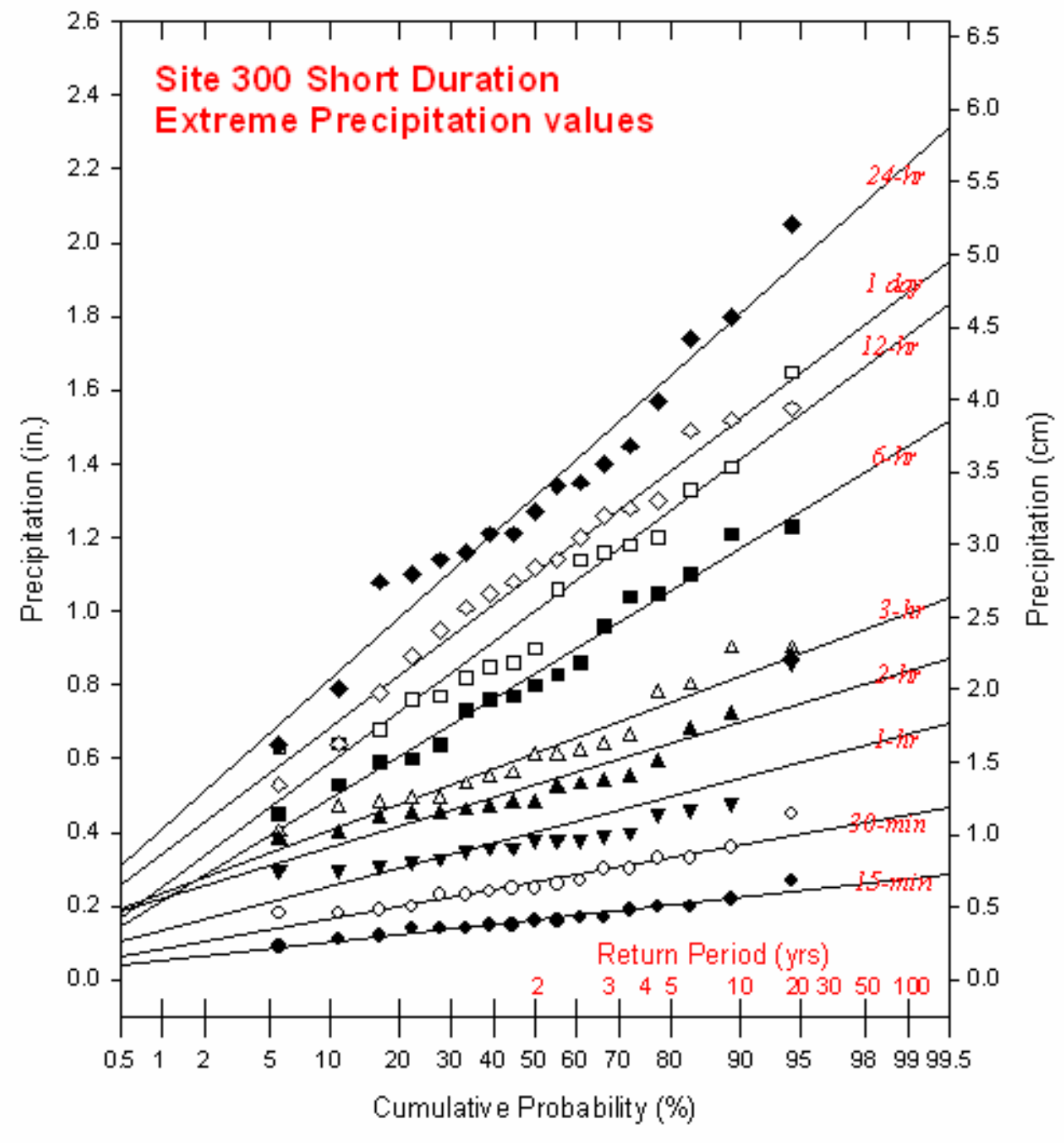

Figure 3.4. Short duration extreme precipitation analysis for Site 300 (1989-1990 through 2005-2006). 


\section{HOURLY PRECIPITATION MEANS AND FREQUENCIES}

Hourly precipitation means and frequencies were calculated at the Livermore site and Site 300 for each meteorological season based on measurements from August 1989 through August 2006 and January 1989 through August 2006, respectively. Frequency of precipitation is calculated from hours with at least $0.01 \mathrm{in}$. $(0.025 \mathrm{~cm})$ of rainfall, the smallest amount that can be measured by the tipping buckets. The seasonal analyses are plotted in Figure 4.1. Note that mean hourly amounts are plotted as bars using the left scale and frequencies are represented as lines using the right scale.

Winter rainfall amounts and frequency are the largest, about twice as large as the spring values at both sites. Much of the hourly variation results from random fluctuations. However, there does appear to be a maximum in amounts at both sites during the first nine hours of the day in the winter. The frequencies also peak at the fifth and eighth hours at Site 300. The reason for the morning maximum is unknown.

Rainfall frequency decreases by about 50 percent in the spring, or to about one percent of the hours. There is no strong hourly trend in the spring but there is a noticeable increase in rainfall amount and frequency at the Livermore site from hour 14 to hour 16 and also an increase in amount during hours 14 and 15 at Site 300. A separate analysis of only April and May (not shown) indicates a more pronounced peak in precipitation amounts and frequency during the mid-afternoon at both sites. Showers and even thundershowers occasionally occur during the spring and tend to occur in the afternoon when the atmosphere is the warmest from solar radiation.

Rainfall is infrequent and light in the summer. Rainfall increases in the autumn with measurable amounts occurring during only about 0.5 percent of the hours. The rainfall frequencies vary little by hour and the variations in amounts are most likely random and a result of infrequent rain during the autumn (i.e., few sample). 

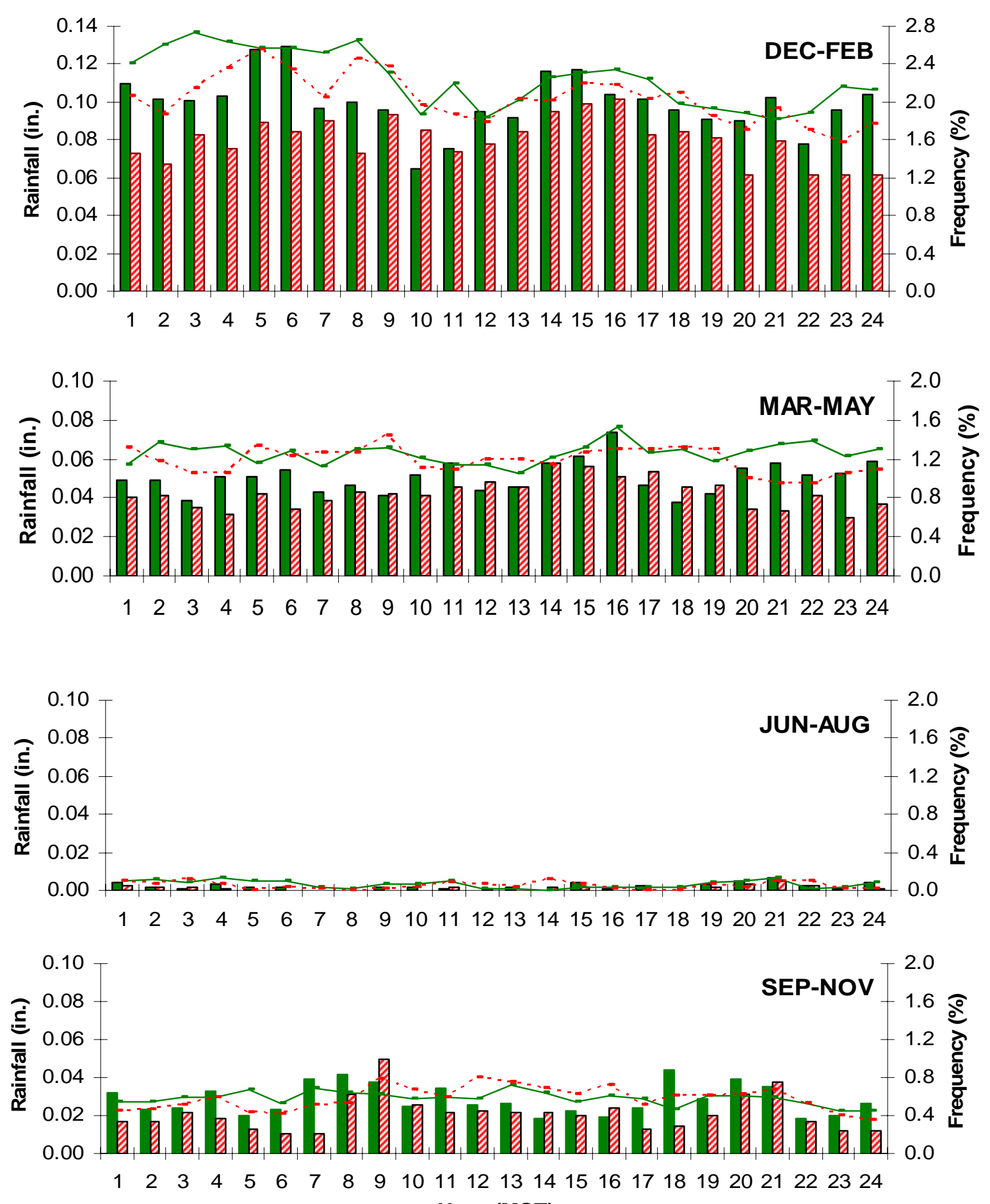

Hour (MST)

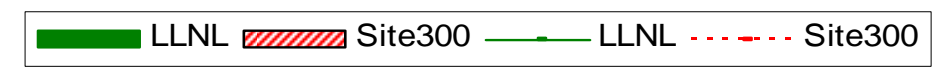

Figure 4.1. Mean hourly (Pacific Standard Time) precipitation amounts and frequencies (\% of hours) at the Livermore site and Site $\mathbf{3 0 0}$ during winter (December to February), spring (March to May), summer (June to August), and fall (September to November). The bars represent precipitation amounts and the lines represent frequencies. The means are based on 15-minute measurements taken from August 1989-August 2006 at the Livermore site and from January 1989-August 2006 at Site 300. 


\section{HISTORICAL DATA}

Livermore site and Site 300 seasonal rainfall totals are plotted for the entire measurement record and are represented as bars in Figures 5.1 and 5.2. In addition, colored solid and dashed lines indicate the 5- and 10-year trailing averages and the straight, black dashed line represents the average for the entire period. The seasonal and annual totals are also given for both sites in Table 5.1. Note the large variability of precipitation by season at both sites. The precipitation in the wettest year is approximately 5.7 and 6.2 times that of the driest years at the Livermore site and Site 300, respectively. This corresponds to a difference of 25.19 and 19.82 inches between the wettest and driest years at the Livermore site and Site 300, respectively.

Note the prominent maximum of rainfall that occurred during 1982-83 at both sites during a strong El Niño. A study by Null (2001) points out 512 weather stations in California set their all-time record for greatest seasonal precipitation during this very strong El Niño. Another study by Null (2004) indicates that strong El Niño events are associated with above-normal rainfall in all climatic divisions in California. During the four strong El Niño events since 1950 (1972-1973, 1982-1983, 1991-1992, and 1997-1998), seasonal rains at both sites were indeed much above normal except for 1991-1992. The three wettest years at Site 300 and three of the four wettest years at the Livermore site occurred during the four strong El Niños. The third and fourth wettest years at the Livermore site and Site 300, respectively, occurred during the weak-to-moderate El Niño of 1994-95. While Null (2004) shows little correlation of La Niña (cooling of eastern Pacific Ocean water) with San Francisco Bay area precipitation, the driest year at both sites (1975-1976) and the third driest at Site 300 (1988-1989) occurred during two of the three strong La Niñas that have occurred during the precipitation record at the two sites. In addition, the second driest year at both sites occurred in 1971-1972 during a weak-tomoderate La Niña.

The 5-and 10-year trailing averages indicate that after relatively little variation in seasonal rainfall through the early 1980s, several short-term trends clearly developed with sharp seasonal variations. The five-year period ending in 1985-1986 was unusually wet especially at the Livermore site with four of the five seasons receiving above-normal rainfall, including the wettest season of 1982-1983. The following six and five respective seasons at the Livermore site and Site 300 experienced below-normal rainfall. Another wet period occurred at both sites during the six years ending in 1997-1998 with four of the seasons experiencing heavy rainfall. This was followed by yet another six consecutive years with below-normal rainfall ending in 2003-2004.

The entire precipitation measurement record is shown in Table 5.1. Statistical summaries for the two 30-year periods ending in 1990 and 2000 are shown in Table 5.2. The latest 30-year normal rainfall (1971-2000) is greater than the previous 30-year period ending in 1990 as well as the entire record, because it includes the wet years in the 1990s and does not include the dry years of the mid-1960s. However the median rainfalls generally do not increase for the 30-year period ending in 2000. 


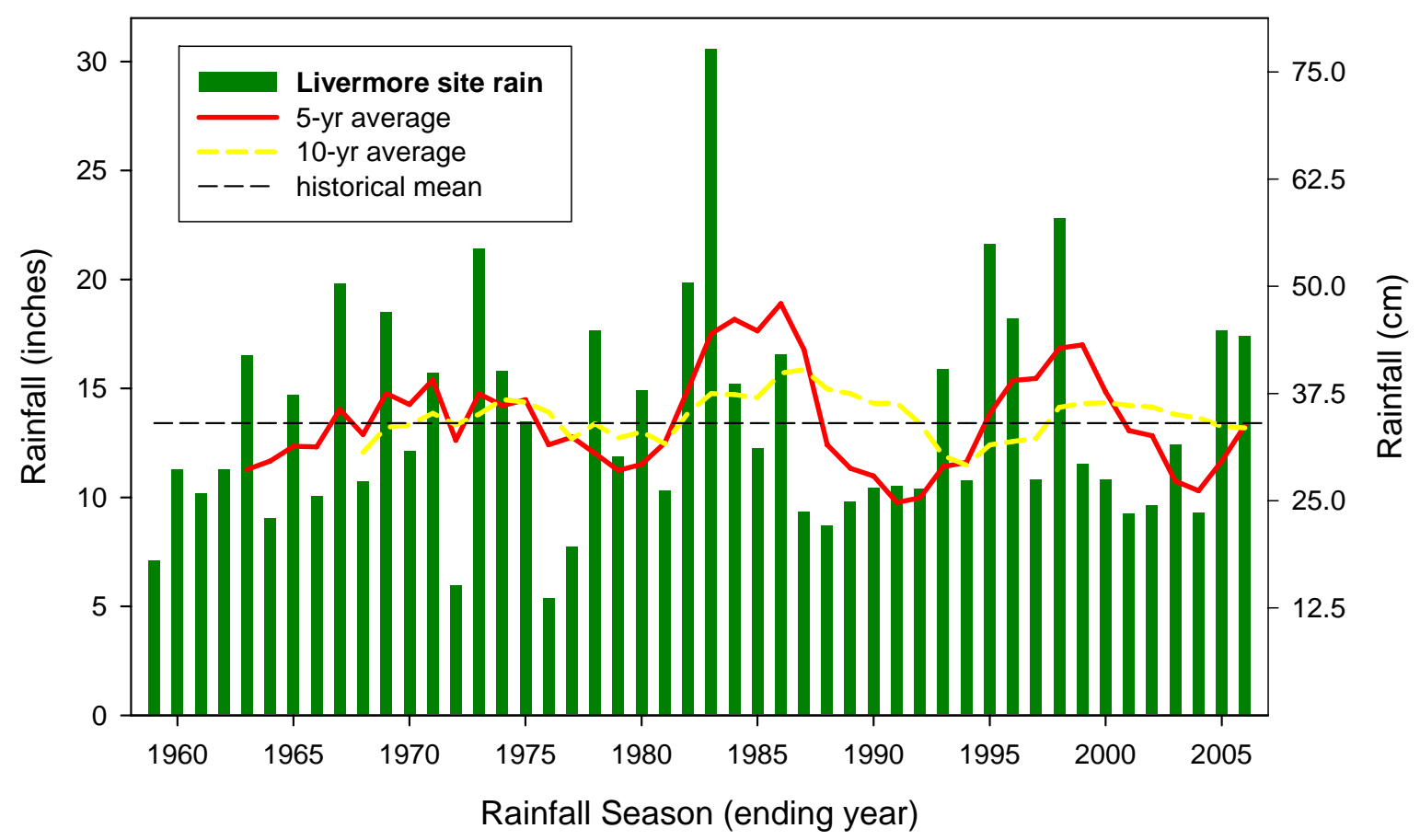

Figure 5.1. Livermore site historical seasonal precipitation. Black dashed line indicates mean over entire measurement period.

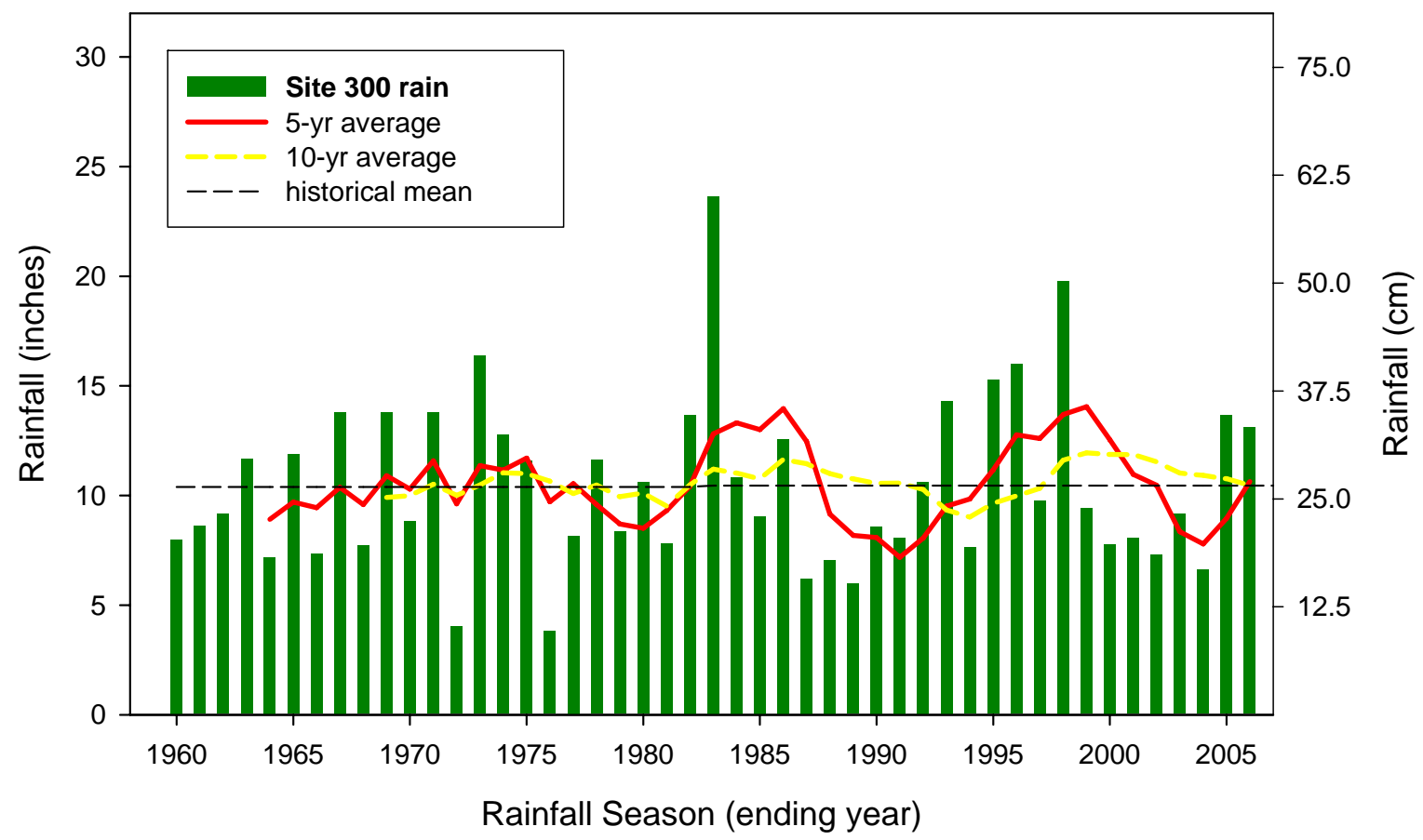

Figure 5.2. Site $\mathbf{3 0 0}$ historical seasonal precipitation. Black dashed line indicates mean over entire measurement period. 
Table 5.1. Livermore site and Site $\mathbf{3 0 0}$ seasonal and annual precipitation. Seasonal precipitation is rainfall for the 12-month period ending on June 30 of the indicated year.

\begin{tabular}{|c|c|c|c|c|}
\hline \multirow{2}{*}{ Year } & \multicolumn{2}{|c|}{ Rainfall season precipitation (in.) } & \multicolumn{2}{|c|}{ Annual precipitation (in.) } \\
\hline & Livermore site & Site 300 & Livermore site & Site 300 \\
\hline 1959 & 7.10 & - & 18.39 & - \\
\hline 1960 & 11.28 & 7.99 & 9.25 & - \\
\hline 1961 & 10.20 & 8.60 & 12.14 & 9.40 \\
\hline 1962 & 11.27 & 9.15 & 9.68 & 7.57 \\
\hline 1963 & 16.54 & 11.65 & 13.58 & 10.84 \\
\hline 1964 & 9.04 & 7.18 & 15.38 & 10.46 \\
\hline 1965 & 14.69 & 11.88 & 11.73 & 10.63 \\
\hline 1966 & 10.07 & 7.33 & 14.75 & 10.67 \\
\hline 1967 & 19.83 & 13.81 & 8.96 & 5.89 \\
\hline 1968 & 10.74 & 7.72 & 17.05 & 12.23 \\
\hline 1969 & 18.52 & 13.77 & 13.58 & 10.34 \\
\hline 1970 & 12.15 & 8.82 & 15.80 & 11.33 \\
\hline 1971 & 15.70 & 13.78 & 18.91 & 15.15 \\
\hline 1972 & 5.95 & 4.03 & 9.34 & 7.34 \\
\hline 1973 & 21.43 & 16.38 & 11.91 & 8.22 \\
\hline 1974 & 15.82 & 12.77 & 20.89 & 17.03 \\
\hline 1975 & 13.49 & 11.57 & 9.64 & 9.17 \\
\hline 1976 & 5.38 & 3.82 & 13.01 & 9.86 \\
\hline 1977 & 7.72 & 8.16 & 6.57 & 5.61 \\
\hline 1978 & 17.67 & 11.62 & 7.88 & 7.41 \\
\hline 1979 & 11.89 & 8.35 & 15.85 & 9.96 \\
\hline 1980 & 14.93 & 10.61 & 14.84 & 10.52 \\
\hline 1981 & 10.32 & 7.82 & 11.74 & 9.36 \\
\hline 1982 & 19.85 & 13.67 & 15.91 & 10.37 \\
\hline 1983 & 30.57 & 23.64 & 20.89 & 17.29 \\
\hline 1984 & 15.20 & 10.84 & 33.57 & 23.58 \\
\hline 1985 & 12.25 & 9.05 & 10.80 & 7.68 \\
\hline 1986 & 16.56 & 12.58 & 10.08 & 7.84 \\
\hline 1987 & 9.35 & 6.20 & 13.16 & 9.75 \\
\hline 1988 & 8.69 & 7.06 & 12.42 & 8.69 \\
\hline 1989 & 9.82 & 5.98 & 8.18 & 5.80 \\
\hline 1990 & 10.45 & 8.58 & 9.57 & 6.69 \\
\hline 1991 & 10.54 & 8.07 & 9.05 & 6.96 \\
\hline 1992 & 10.40 & 10.63 & 10.89 & 8.96 \\
\hline 1993 & 15.87 & 14.31 & 11.95 & 12.00 \\
\hline 1994 & 10.76 & 7.63 & 15.81 & 12.53 \\
\hline 1995 & 21.62 & 15.26 & 11.93 & 8.95 \\
\hline 1996 & 18.18 & 16.00 & 21.30 & 16.23 \\
\hline 1997 & 10.84 & 9.78 & 19.71 & 17.28 \\
\hline 1998 & 22.82 & 19.79 & 9.84 & 7.60 \\
\hline 1999 & 11.55 & 9.40 & 20.58 & 18.69 \\
\hline 2000 & 10.83 & 7.78 & 9.63 & 7.78 \\
\hline 2001 & 9.28 & 8.04 & 11.63 & 10.01 \\
\hline 2002 & 9.62 & 7.32 & 13.36 & 9.74 \\
\hline 2003 & 12.44 & 9.17 & 10.66 & 8.65 \\
\hline 2004 & 9.31 & 6.61 & 9.42 & 6.71 \\
\hline 2005 & 17.66 & 13.65 & 10.96 & 7.96 \\
\hline 2006 & 17.40 & 13.10 & 15.24 & 12.68 \\
\hline
\end{tabular}


Table 5.2. Livermore site and Site $\mathbf{3 0 0}$ seasonal and annual precipitation. The 30 -year means (normals) and medians for seasonal rainfall start and end on July 1 and June 30, respectively, on the indicated years.

\begin{tabular}{|c|c|c|c|c|}
\hline \multirow{2}{*}{ Years } & \multicolumn{2}{|c|}{ Rainfall season precipitation (in.) } & \multicolumn{2}{|c|}{ Annual precipitation (in.) } \\
\hline & Livermore site & Site 300 & Livermore site & Site 300 \\
\hline \multicolumn{5}{|l|}{ 1961-1990 } \\
\hline Mean +/- std. dev. & $13.54+/-5.26$ (in.) & $10.21+/-3.98$ (in.) & $13.49+/-5.31$ (in.) & $10.14+/-3.86$ (in.) \\
\hline Median & $12.20 \mathrm{in.}$ & $9.10 \mathrm{in.}$ & $12.72 \mathrm{in.}$ & $9.81 \mathrm{in.}$ \\
\hline Number of years & 30 & 30 & 30 & 30 \\
\hline \multicolumn{5}{|l|}{ 1971-2000 } \\
\hline Mean +/- std. dev. & $13.88+/-5.54$ (in.) & $10.84+/-4.45$ (in.) & $13.62+/-5.65$ (in.) & $10.64+/-4.37$ (in.) \\
\hline Median & $12.07 \mathrm{in.}$ & $10.20 \mathrm{in.}$ & 11.92 in. & 9.27 in. \\
\hline Number of years & 30 & 30 & 30 & 30 \\
\hline \multicolumn{5}{|l|}{ 1958-2006 } \\
\hline Mean +/- std. dev. & $13.41+/-4.96$ (in.) & $10.45+/-3.91$ (in.) & $13.58+/-4.82$ (in.) & $10.47+/-3.74$ (in.) \\
\hline Median & $11.72 \mathrm{in.}$ & $9.17 \mathrm{in.}$ & $12.14 \mathrm{in.}$ & 9.75 in. \\
\hline Number of years & 48 & 47 & 49 & 47 \\
\hline
\end{tabular}




\section{SUMMARY}

The annual rainfall distribution at both the Livermore site and Site 300 is typical of Mediterranean climates, with most rainfall occurring during the cold season. Nearly $80 \%$ of seasonal rainfall occurs during November through March, with the average annual rainfall equaling 13.62 and 10.64 inches at the Livermore site and Site 300, respectively. Rainfall typically is heaviest during January and February. Site 300 receives less rain than the Livermore site because it has a longer fetch of higher terrain to the south and southwest, thereby creating a more pronounced rain shadow effect during winter storms when winds are frequently southerly to southwesterly. Calculations of various return periods of rainfall used for engineering and planning indicate considerably smaller amounts than from NOAA Atlas 2 values. For instance, the NOAA atlas values for the 100-year return period considerably overestimate values calculated from measurements at the Livermore site and Site 300 by $71 \%$ and 37\%, respectively, for the 6-hour rainfall and by approximately $80 \%$ for the 24-hour rainfall at both sites. An analysis of hourly rainfall by season indicates primarily random variations except for a pronounced maximum during early morning hours during winter and a slight mid-afternoon peak during spring. Finally, an historical analysis of seasonal rainfall indicates a large variability by season at both sites. The precipitation in the wettest season is approximately 5.7 and 6.2 times that of the driest season at the Livermore site and Site 300, respectively. The wettest rainfall seasons at both sites typically occurred during strong El Niños. 


\section{Appendix A. Location of Livermore Site Rain Gauge and Meteorological}

\section{Tower}

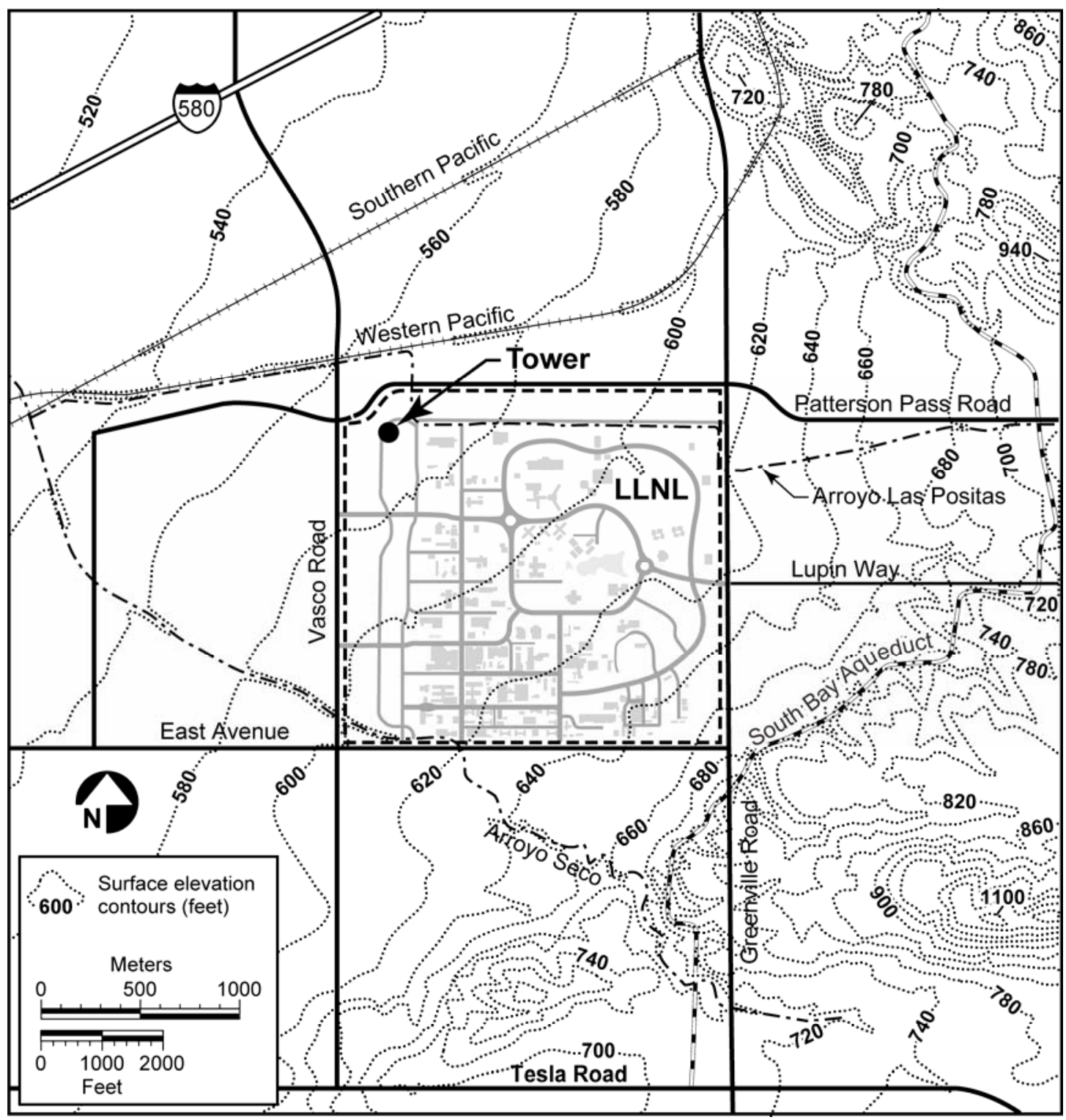




\section{Appendix B. Location of Site 300 Rain Gauge and Meteorological Tower}

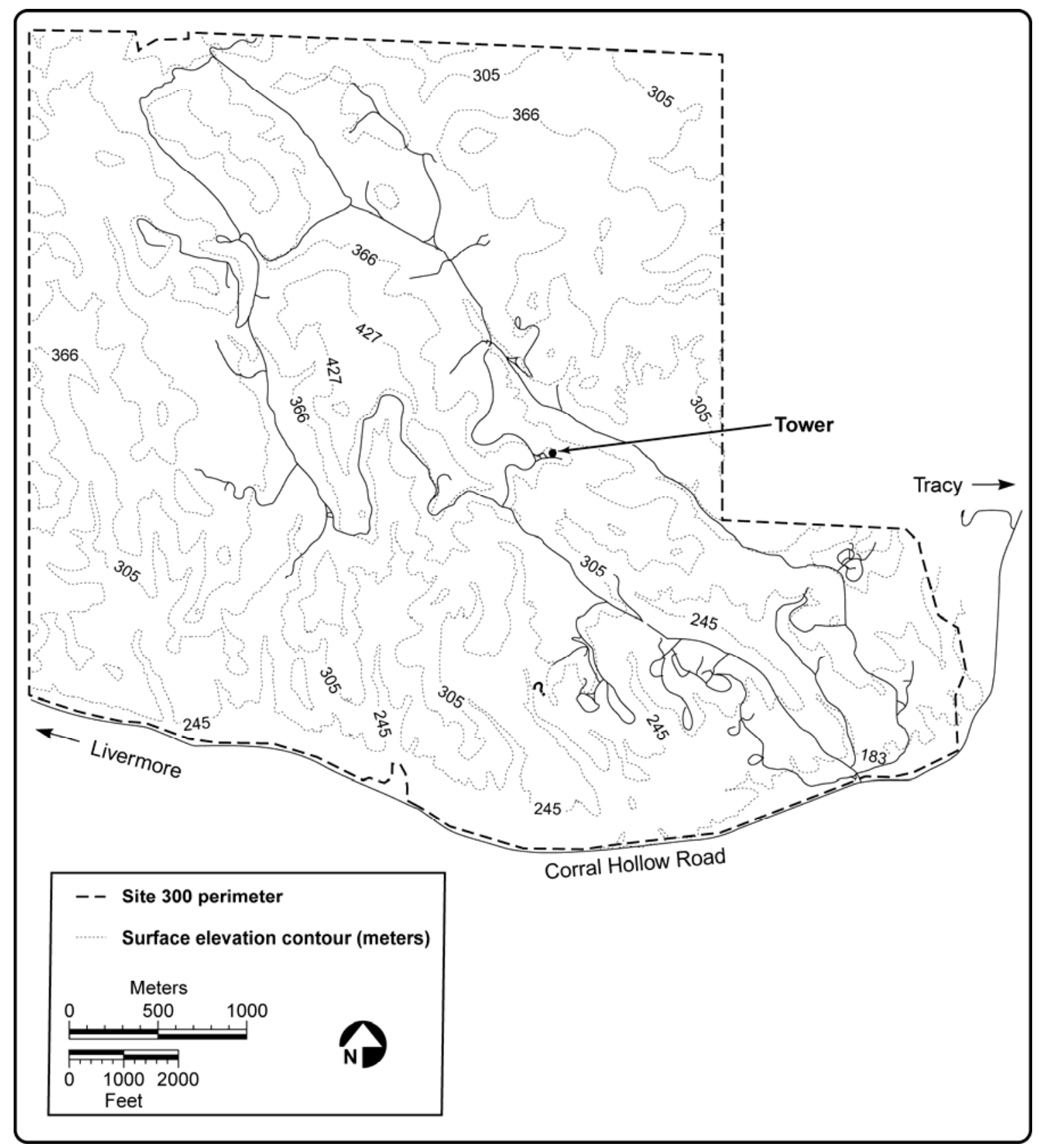




\section{Appendix C. Location Statistics of Rain Gauges}

\begin{tabular}{|c|c|c|}
\hline Station: & LLNL, Livermore, CA & Site 300 , San Joaquin County, CA \\
\hline Longitude: & $\begin{array}{l}121^{\circ} 42^{\prime} 54^{\prime \prime} \text { W } \\
\text { (UTM coordinate: } 613143 \mathrm{mE} \\
\text { on } 1230 \text { W Central Meridian) }\end{array}$ & $\begin{array}{l}121^{\circ} 31^{\prime} 30^{\prime \prime} \\
\text { (UTM coordinate: } 630120 \mathrm{mE} \text { on } 1230 \mathrm{~W} \\
\text { Central Meridian) }\end{array}$ \\
\hline Latitude: & $\begin{array}{l}37^{\circ} 41^{\prime} 36^{\prime \prime} \mathrm{N} \\
\text { (UTM coordinate: } 4172286 \mathrm{mN} \text { ) }\end{array}$ & $\begin{array}{l}37^{\circ} 39^{\prime} 13^{\prime \prime} \\
\text { (UTM coordinate: } 4168107 \mathrm{mN} \text { ) }\end{array}$ \\
\hline $\begin{array}{l}\text { Elevation above sea } \\
\text { level: }\end{array}$ & 572 feet (174 meters) & 1,220 feet (372 meters) \\
\hline Magnetic declination: & $17^{\circ}$ east & $17^{\circ}$ east \\
\hline
\end{tabular}




\section{Appendix D. Rain Gauge History and Estimated Accuracy}

\begin{tabular}{|c|c|c|c|c|}
\hline Site & Dates & Instrument & Accuracy* & Comments \\
\hline \multicolumn{5}{|l|}{ Livermore site } \\
\hline SE (Bldg. 112) & 2/28/58-8/31/89 & Accumulation gauge & $+/-5 \%$ daily & $\begin{array}{l}\text { Emptied daily except for } \\
\text { weekends and holidays }\end{array}$ \\
\hline NW (tower) & 9/1/89-12/15/04 & $\begin{array}{l}\text { 8-inch tipping bucket } \\
\text { (Handar 600-0753) }\end{array}$ & $+2 \%$ to $-4 \%$ & $\begin{array}{l}\text { Continuous 15-minute } \\
\text { measurements }\end{array}$ \\
\hline NW (tower) & $\begin{array}{l}\text { 12/15/04- } \\
\text { present }\end{array}$ & $\begin{array}{l}\text { 12-inch tipping bucket } \\
\text { (NovaLynx 260-2500) }\end{array}$ & $+2 \%$ to $-3 \%$ & $\begin{array}{l}\text { Larger diameter gauge: } \\
\text { improved catch }\end{array}$ \\
\hline \multicolumn{5}{|l|}{ Site 300} \\
\hline & 9/59-11/30/88 & Accumulation gauge & $+/-5 \%$ daily & $\begin{array}{l}\text { Emptied daily except for } \\
\text { weekends and holidays }\end{array}$ \\
\hline & 12/1/88-1/5/05 & $\begin{array}{l}\text { 8-inch tipping bucket } \\
\text { (Handar 600-0753) }\end{array}$ & $+2 \%$ to $-4 \%$ & $\begin{array}{l}\text { Continuous } 15 \text {-minute } \\
\text { measurements }\end{array}$ \\
\hline & 1/5/05-present & $\begin{array}{l}\text { 12-inch tipping bucket } \\
\text { (NovaLynx 260-2500) }\end{array}$ & $+2 \%$ to $-3 \%$ & $\begin{array}{l}\text { Larger diameter gauge: } \\
\text { improved catch }\end{array}$ \\
\hline
\end{tabular}

*Note: Rain gauges have possible errors:

1. Representativeness: Because a rain gauge is a single point measurement, it may under- or overrepresent nearby areas that, possibly, have large differences in showers.

2. Wind: Wind flow is disturbed by the gauge and some small droplets may not drop into the gauge, thereby causing underestimation. The amount of underestimation depends upon wind speed, raindrop size distribution, gauge diameter, and if a windshield is used. (The switch to a largerdiameter rain gauge increases rainfall catch. Stronger winds at Site 300 will cause more underestimation.)

3. Wetting and evaporation: As a light rain falls into a dry gauge, some water will adhere to the funnel surface and to the screens, thereby delaying the measurement of the actual rainfall. A small amount of the water can also evaporate.

4. Splash out: Large water drops that hit the top part of the funnel may break up, causing some of the water to splash out of the gauge.

5. Plugging: Small objects such as grass may blow into the gauge, slip pass the filters, and reduce flow through the funnel.

6. Tipping bucket:

a) During heavy rains, some water will fall into full buckets during the finite time it takes the bucket to tip.

b) Tipping buckets can jam and provide no output during rainfall. Spider webs are the most frequent reason for jams. Weekly bucket maintenance since early 2003 ensures jams do not occur.

7. Accumulation rain gauge:

a) Random observer errors can occur with the same and different observers.

b) Measurements are usually not available for calendar days (midnight to midnight).

c) 24-hour measurements require the observer to make readings at exact time each day.

d) If the observer misses one or more daily readings, it is impossible to determine daily rainfall. 


\section{REFERENCES}

Ahrens, D.C., Meteorology Today-An Introduction to Weather, Climate, and the Environment, $7^{\text {th }}$ Edition, Brooks-Cole-Thomson Learning, 2003.

Gouveia, F.J. and K.R. Chapman, Climatology of Lawrence Livermore National Laboratory. UCID21686, Lawrence Livermore National Laboratory, 1989.

Makkonen, L., Plotting positions in extreme value analysis, Journal of Applied Meteorology 45, 334340, 2006.

National Oceanic and Atmospheric Administration, 1973, NOAA Atlas 2: National Weather Service, Hydrometeorological Design Studies Center, Precipitation Frequency Data Server for the Western United States, http://www.nws.noaa.gov/ohd/hdsc/noaaatlas2.htm\#disclaimer, accessed November 22, 2005.

Null, J., El Niño and La Niña...Their Relationship to California Flood Damage, http://ggweather.com/nino/calif_flood.html, Updated October 7, 2001.

Null, J., An Analysis of El Niño, La Niña and California Rainfall, http://ggweather.com/enso/calenso.htm, Updated October 2004.

Reneau, S. L., G. A. Kuyumjian, D. V. Malmon, and M. F. Tardiff, Precipitation frequency relations on the Pajarito Plateau and in the Eastern Jemez Mountains, New Mexico, and examples of extreme or flood-producing storms. LA-UR-03-6484, Los Alamos National Laboratory, November 2003.

Weibull, W., A statistical theory of strength of materials, Ing. Vetensk. Akad. Handl. 151, 1-45,1939. 